\title{
Socketed Two-bladed Arrowheads of the Scythian Type from the Burial Grounds of Azerbaijan and their Connection with the Burial Rites of Aral Sea Region
}

\section{Hasanov Zaur}

PhD, Senior Researcher, Institute of Archaeology and Ethnography, Azerbaijan National Academy of Sciences. H. Cavid pr. 115., Baku, Az-1143, Azerbaijan. Email: zaurmail@gmail.com

Summary. The paper is dedicated to the socketed two-bladed arrowheads of the Scythian type from the eastern part of the North and South Caucasus. Archaeological complexes (and their rituals) from which the two-bladed arrowheads originate are described. In Mingechaur and Apsheron the ceramic vessels were located near the feet of the deceased. This ritual has parallels in Uigarak. The most archaic rhomboid two-bladed arrowheads originate from the burials, without iron objects, in Yonjaly necropolis in Sheki. Craniometric data from the neighboring Tepebashy necropolis in Sheki, shows similarity with the sculls of parallel groups of Sakas from the Aral Sea vicinity. In the same necropolis there were found collective burials with the traces of fire ritual, which have parallels in the Sacar-Chaga 6 burial ground.

Keywords. Socketed two-bladed arrowheads; Azerbaijan; South Aral Area; Sakar-Chaga 6; Uigarak; Early Scythian period.

\section{Әзербайжанның жерлеу орындарынан табылған скифтердің екіқанатты ұңғымалы жебе ұштары мен олардың Арал маңындағы жерлеу салтымен байланысы}

\section{Гасанов Заур Гасан-оғлы}

PhD, Жетекші ғылыми қызметкер, Әзібайжан Ұлттық ғылым академиясының археология және этнография Институты. Н. Cavid pr. 115., Baku, Az-1143, Azerbaijan. Email: zaurmail@gmail.com

Аңдатпа. Бұл жұмыста Солтүстік және Оңтүстік Кавказдың шығыс бөлігінен скифтер түрінің екі жүзді жебелерін талдаймыз. Екі жүзді скифтік жебелер табылған кешендер (және олардың рәсімдері) сипатталған. Мингечаур және Абшеронда керамикалық ыдыстар жерленгендердің аяқ тұсына орнатылған, дәл осындай сәйкестік Уйгарахта анық байқалады. Темір заттар жоқ қорымдардың ішіндегі ең көнесі Шекидегі Йонджали мазарындағы екі жүзді ромбалы жебелер. Көрші Тепебаши мазарында Арал аймағындағы сақ тайпаларының синхронды топтарына ұқсастығы бар сүйектер табылды. Осы жерде оңтүстік өңірлердегі Сакар-Чаг 6 қорымына ұқсас от ғұрпының іздері бар ұжымдық көму бар.

Кілт сөздер: екіқанатты ұңғымалы жебе ұштары; Әзірбайжан; Арал маңы; Сакар-чага 6; Уйгарак; скиф архаикасы.

\section{Двухлопастные втульчатые наконечники стрел скифского типа из захоронений Азербайджана и их связь с обрядом погребения Приаралья}

\section{Гасанов Заур Гасан-оглу}

$\mathrm{PhD}$, Ведущий научный сотрудник, Институт археологии и этнографии Национальной академии наук Азербайджана. Н. Cavid pr. 115, Baku, Az-1143, Azerbaijan. Email: zaurmail@gmail.com

Аннотация. В работе анализируются втульчатые двухлопастные наконечники стрел скифского типа из восточной части Северного и Южного Кавказа, описываются комплексы (и их ритуалы), из которых происходят двухлопастные скифские стрелы. В Мингечауре и Апшероне керамические сосуды устанавливались в ногах погребенных, что также прослеживается в Уйгараке. Из погребений без железных предметов, найденных в некрополе Йонджалы в Шеки, происходят наиболее архаические двухлопастные ромбические наконечники стрел. В соседнем некрополе Тепебаши обнаружены черепа, имеющие сходство с синхронными группами сакских племен из Приаралья, отсюда же происходят коллективные погребения со следами огненного ритуала, имеющие параллели в могильнике Сакарчага 6 в Южном Приаралье.

Ключевые слова: втульчатые двухлопастные наконечники стрел; Азербайджан; Приаралье; Сакар-чага 6; Уйгарак; скифская архаика. 
әОЖ/ УДк 902

\section{Двухлопастные втульчатые наконечники стрел скифского типа из захоронений Азербайджана и их связь с обрядом погребения Приаралья}

\section{Гасанов 3.Г.}

В период раннего железного века в некоторых погребениях Азербайджана были обнаружены втульчатые двухлопастные наконечники стрел скифского типа. Проблема заключалась в определении того, к кому следует относить эти находки - к скифам или же местному населению? По сложившейся традиции большинство исследователей, изучавших следы пребывания скифов на Южном Кавказе, как правило, ограничивались наличием элементов «скифской триады» для выявления скифских памятников. (Под скифской «триадой» в скифологии начиная с 1950 гг. подразумеваются 1) определенные типы оружия; 2) и конского убора; 3) звериный стиль искусства (Ольховский 1997). Обряд захоронения, как правило, либо игнорируется, либо анализируется очень поверхностно. В монографии С.А. Есаяна и М.Н. Погребовой вопросы обряда захоронения скифов не анализируются и все исследование практически сведено к анализу вещей, составляющих скифскую "триаду» (Есаян, Погребова, 1985). В частности, они пишут: «В понятие «элементы скифской культуры» мы включаем те вещи, органическая связь которых с культурой скифов Причерноморья не вызывает сомнений» (Есаян, Погребова, 1985). Другими словами, все их исследование базируется на элементах вещей скифской «триады».

Об ошибочности изолированного использования скифской «триады» в качестве основного показателя идентификации скифских погребений писали многие авторы. В.С. Ольховский посвятил этому вопросу специальную статью, в которой он предлагает расширить понятие скифской «триады» и ввести дополнительные диагностирующие признаки этнокультурной реконструкции (Ольховский 1997, С.85-96). С целью решения данной проблемы в статье предлагается проанализировать обряд и некоторые дополнительные материалы погребений, из которых происходят эти находки (по данной проблеме см.: также Гасанов 2012, C.519-527).

На северных склонах восточной части Кавказа наиболее ранние образцы втульчатых двухлопастных наконечников стрел скифского типа были обнаружены в поселении Сержень-юрт и в Дербенте. Далее находки этих изделий были обнаружены на Апшеронском полуострове. По мнению исследователей, подобная география распространения этих находок свидетельствует об их продвижении с севера на юг через Дербентский проход. Прежде чем приступить к описанию самих находок и комплексов, из которых они происходят, следует вкратце коснуться проблемы датировок и классификации двухлопастных наконечников стрел скифского типа.

В соответствии с классификацией А.И. Мелюковой, двухлопастные втульчатые наконечники стрел разделяются на шесть типов, каждый из которых делится на несколько вариантов. Двухлопастные наконечники с ромбической головкой она относит к первому типу и разделяет на пять вариантов. Это наиболее ранние двухлопастные наконечники (Мелюкова 1964, С.18, табл. V). По А.И. Мелюковой, все наконечники стрел первого типа ведут свое происхождение «от наконечников стрел с ромбовидной головкой и недлинной втулкой VIIIVII вв. до н.э.» (Мелюкова 1964, С.18). 
Наконечники стрел этого типа имеют различные названия в научной литературе. Часто их называют наконечниками типа «Жаботин» по месту находок колчанного набора из кургана 524 у с. Жаботин в Днепровской Правобережной лесостепи (Ильинская 1975, табл. VII). Они также часто называются наконечниками типа «Енджа» по месту находок из погребения 1 кургана 2 у с. Енджа (Царевброд) в Северной Болгарии (Рисунок 1:16-17, 42-44). Также было предложено называть их наконечниками типа «Енджа-Жаботин» или «Zhabotin-Endge» (Иcмагилов 1988, С.35; Полін 1987, С.20; Рябкова 2014, С.379; Stantchev 2000, Р.36).

B.A. Ильинская пришла к выводу о том, что жаботинские наконечники с ромбическим пером и выступающей втулкой ведут своё происхождение от наконечников типа Енджа с длинно-ромбическим асимметричным пером (Ильинская 1975, С.65-66). То есть наконечники стрел из Енджи относятся к наиболее ранним двухлопастным ромбическим наконечникам стрел скифского типа. В Северной Болгарии известны и другие погребения с наконечниками стрел этого наиболее раннего типа. Например, могила №5 из с. Польско Косово в нижнем течении р. Янтра. Все бронзовые наконечники из этого захоронения относятся к двухлопастным ромбическим наконечникам с короткой втулкой. Всего из данного комплекса происходит 30 наконечников стрел этого типа (15 с шипом и ещё 15 без шипа) (Рисунок 1:25-26, 47-48). Д. Станчев относит это погребение к концу VIII - началу VII в. до н.э. (Stantchev 2000, Р.35-44). Я. Хохоровский также датирует появление раннескифских находок (включая вышеописанные ромбические наконечники стрел из Енджи) «на пограничье Восточной и Центральной Европы» рубежом VIII-VII вв. до н.э. (Хохоровский 2011, C.9-10). Скифские наконечники из с.Енджа (Царевброд) датированы В.А. Ильинской и А.И. Тереножкиным не позднее начала VII в. до н.э. (Ильинская, Тереножкин 1983, С.19-20).

Относительно датировок ромбических стрел из кургана 524 у с.Жаботин существуют различные мнения. В.А. Ильинская относила этот курган к докелермесскому периоду (Ильинская 1975, С.62), а С.В. Махортых синхронизирует его с келермесскими курганами (Махортых 2014, С.76). Л.К. Галанина датирует наиболее ранние келермесские курганы приблизительно 660-640 гг. до н.э. (Галанина 1997, С.192). С.А. Скорый датирует курган 524 у с.Жаботин началом первой четверти VII в. до н.э., С.В. Полин - VIII-VII вв. до н.э., М.Н. Дараган периодом не позднее конца VIII в. до н.э., Т.В. Рябкова - периодом ближе к середине VIII в. до н. э. (Дараган 2011, С.572; Полін 1987, С.22-23; Рябкова 2014, С.412; Скорый 2003, Р.39-40). Несмотря на то, что в абсолютной хронологии В.А. Ильинской, С.А. Скорого, С.В. Полина, М.Н. Дараган и Т.В. Рябковой есть некоторые отличия, все исследователи относят курган 524 у с. Жаботин к докелермесскому периоду, т.е. их относительная хронология совпадает.

А.И. Мелюкова при составлении своей классификации скифских стрел уделила основное внимание двухлопастным лавролистным и осторолистным, а также трехлопастным и трёхгранным наконечникам стрел. Двухлопастные ромбические наконечники стрел хотя и представлены в её таблице, но недостаточно хорошо описаны, что значительно усложняет работу по выделению различных групп этих изделий. Т.В. Рябкова считает, что колчанный набор из кургана 524 у с. Жаботин должен быть ещё раз детально рассмотрен, поскольку в него «входят экземпляры, в значительной мере отличающиеся друг от друга» (Рябкова 2014, С.383). Всего в колчанном наборе из этого кургана было 30 бронзовых двухлопастных наконечников (из которых 26 имеют шипы) и один фррагментированный костяной наконечник (Рябкова 2014, С.379-380). А.И. Мелюкова при определении типов скифских наконечников стрел выделяла следующие 

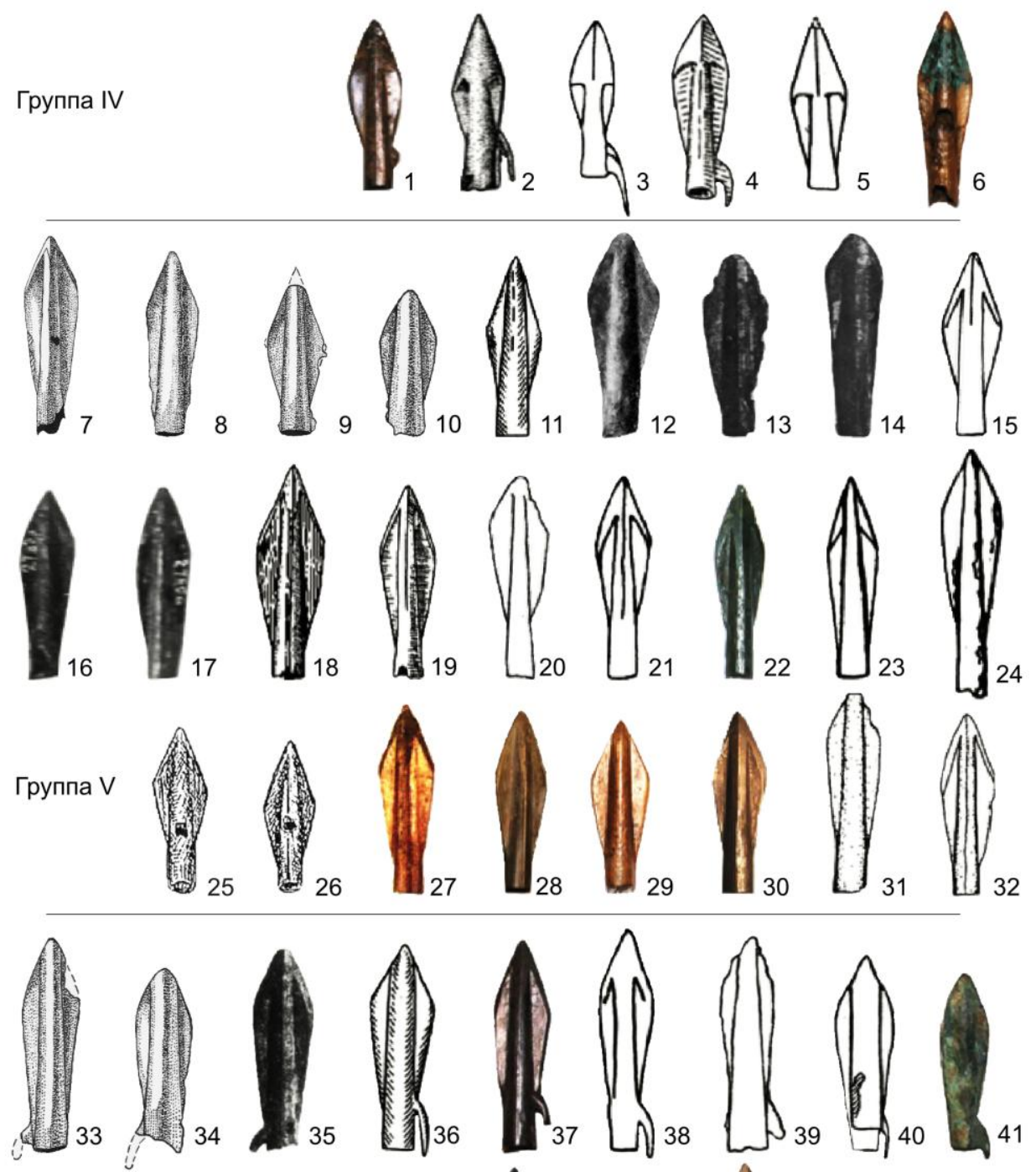

Группа VI
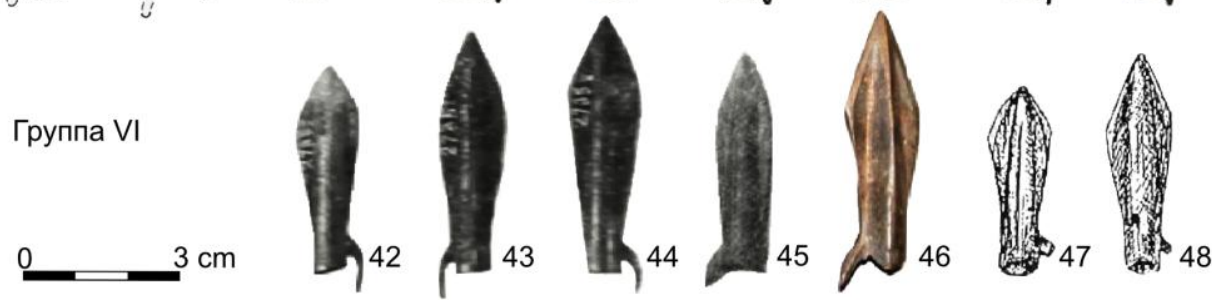

Рисунок 1. 1, 30, 37 - Жаботин, курган 524; 2 - Имирлер; 3 - Амасья; 4 - Карамурун I, курган 5ж; 5 - Сакарчага 6, курган 20; 6, 29 - Уйгарак, курган 39; 7 - Физулинский р-н; 8, 9 - Шеки, некрополь Йонджалы; 8 - погребение в шурфе IV; 9 - погребение в шурфе III;

10, 33-34 - Шамкир, некрополь на холме возле карьера суглинок; 11, 36 - Дербент; 12-14, 35 - Сержень-Юрт; 15 - Красное Знамя, курган 9; 16-17, 42-44 - Енджа, курган 2, погребение 1; 18 - Чиликты, курган 5; 19 - Пожарная балка, поселение; 20 - Холмский, курган 4 погребение 1; 21 - Богазкей; 22, 41 - Келермес, курганы 2-4, раскопки Д.Г. Шульца;

23-24 - Квитки, курган; 25-26, 47-48 - могила 5 из с.Польско-Косово; 27 - Белоградец,

курган; 28, 46 - Большой Гумаровский курган, погребение 3; 31-32 Нонамме-Гора; 38 - Самтавро; 39-40 - Норашен, Астхиблур; 45 - Аржан-1, могила 4 (1-6, 15-24, 27-32 - по Рябкова 2014: рис. І.4, І.5, І.6; 10 - по Кесаманлы, Гусейнова 1980: табл. XIII, Б, 9; 11 - по Кудрявцев 1982: рис. 7: За; 12-14 - по Козенкова 1965: рис. 24: 6; Козенкова, Крупнов 1966: рис. 36: 2-3; 25-26 - по Stantchev 2000: plate II, 3) 

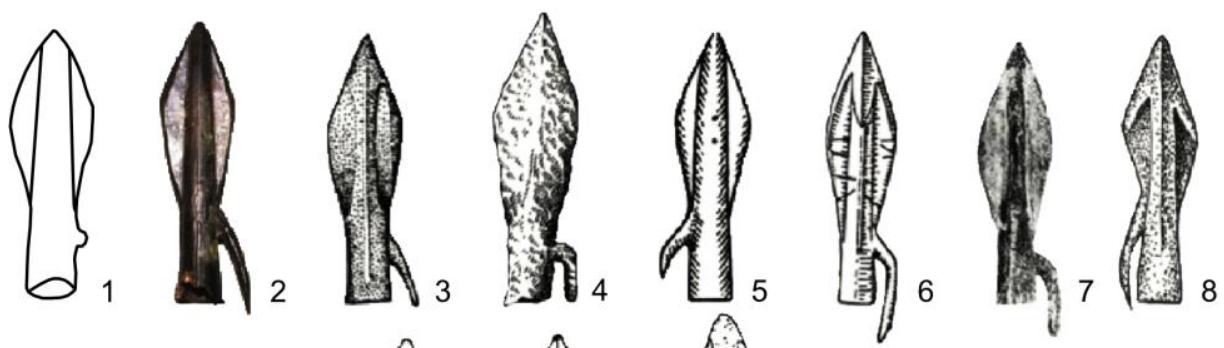

Группа I
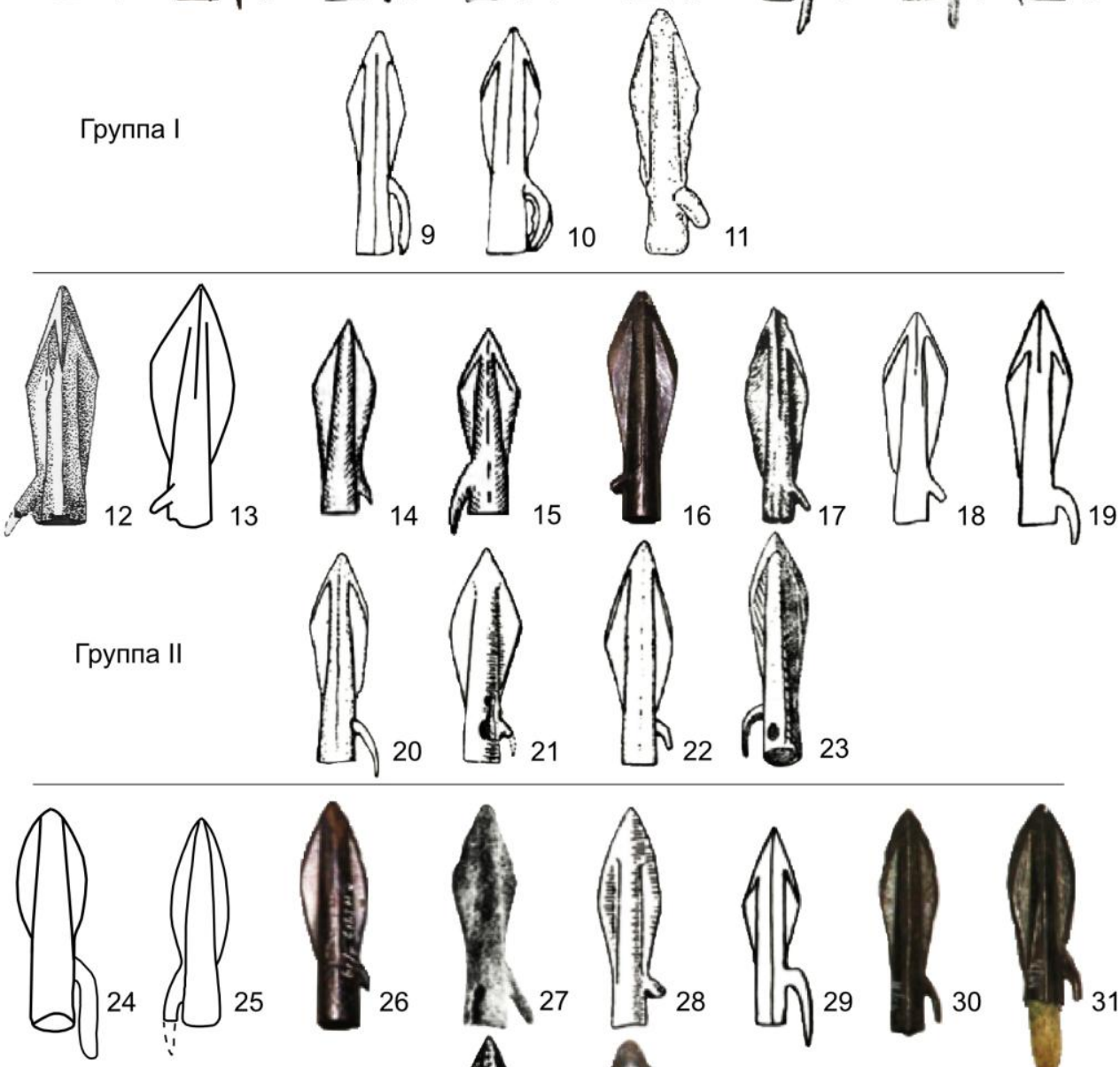

Группа III
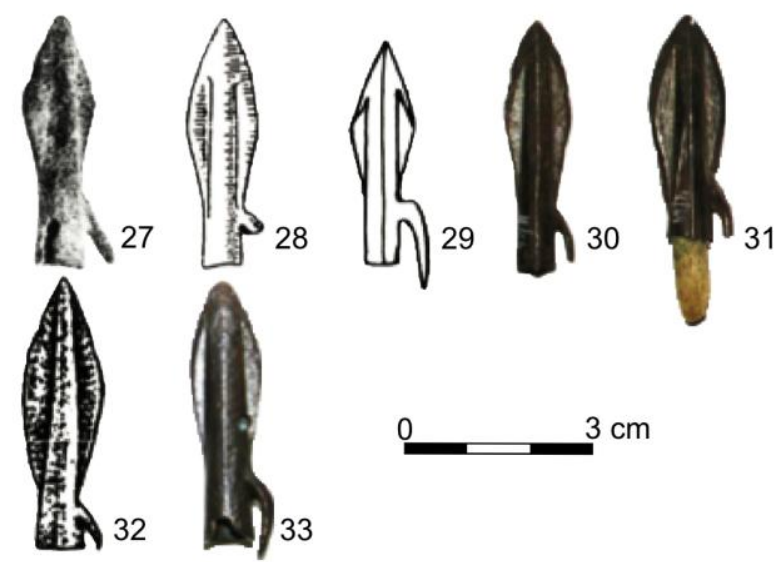

Рисунок 2. 1, 24 - Шамкир, с. Кечили; 2, 16, 26 - Жаботин, курган 524; 3 - Имирлер; 4 - Бажиган; 5, 14-15 - Дербент; 6, 21, 28 - Богазкей; 7, 27 - Тарс; 8 - Самтавро, погребение 27; 9-10 - Музей, г. Тогат, музей г. Испарта; 11, 22 - Каман Кале Хоюк; 12 - Шеки, некрополь Йонджалы, погребение в шурфе IV;

13 - каменный ящик Апшеронского могильника; 17 - Астраханское Заволжье; 18 - Нижнее Поволжье, находки у г. Камышин; 19, 29 - Красное знамя, курган 9; 20 - Нонамме-Гора; 23 - Изюмский уезд; 25 - Мингечаур, грунтовое погребение с вытянутым костяком; 30-31 - Келермес, курган 2-4, раскопки Д. Г. Шульца; 32 - Клады, курган 41; 33 - Журовка, курган 406. (1, 24 - по Кашкай, Селимханов 1973: рис. 15:178; 13 - по Джафрарзаде 1948: табл. 2: 1; 14-15 - по Кудрявцев 1982: рис. 7: 1-3а; 25 - по Ионе 1953: табл. І, 1, а; 2-11, 16-23, 26-33 - по Рябкова 2014: рис. І.1, І.2, І.3) 
признаки: «форма головки, соотношение длины наконечника и его ширины, а также наличие внутренней или наружной втулки и ее размеры» (Мелюкова 1964, С.16). Т.В. Рябкова отмечает, что следует также принять во внимание «такие признаки, как форма, размеры и место прикрепления шипа, наличие выделенной нервюры, доходящей до острия пера, место максимального расширения пера» и размер наконечника, поскольку от него зависит вес и, соответственно, баллистические свойства (Рябкова 2014, С.380). Основываясь на этих признаках, она выделяет шесть групп стрел из колчанного набора из кургана 524 у с.Жаботин (Рябкова 2014, С.372-432). Рисунки, в которые включены шесть групп наконечников стрел (прилагаемые к данной статье), были составлены на основе классификация Рябковой с добавлением в нее информации о наконечниках стрел из Азербайджана (Рисунки 1 и 3). Мы проанализируем наконечники стрел, найденные в регионах, находящихся на пути миграции скифов на Ближний Восток, основываясь на типологических разработках А.И. Мелюковой и Т.В. Рябковой.

Сержень-Юрт. Двухлопастные втульчатые наконечники стрел с ромбическим пером были найдены в Чечено-Ингушетии у с.Сержень-Юрт, расположенного в восточной части предгорий Кавказского хребта, со стороны Каспийского побережья. В.И. Козенкова, Е.И. Крупнов, В.А. Ильинская и А.И. Тереножкин пришли к выводу, что поселение погибло в результате нашествия скифов (Козенкова, Крупнов 1966, С.87; Ильинская, Тереножкин 1983, С.22). По результатам раскопок на поселении Сержень-Юрт в 1963 г. и 1964 гг. было опубликовано четыре двухлопастных втульчатых наконечника стрел с ромбическим пером:

1) наконечник с асимметричным пером и выступающей втулкой. Он не имеет шипа, втулка этого наконечника составляет приблизительно 30\% от общей длины наконечника стрелы. Максимальная ширина пера смещена к острию (Козенкова 1965, С.72, рис.24:6) (Рисунок 1:12). По А.И. Мелюковой, он относится к отделу I, типу 1, варианту 5 двухлопастных наконечников стрел (Мелюкова 1964, табл. V), по Т.В. Рябковой - к 5 группе (Рябкова 2014, рис. 1:5);

2) два наконечника стрел без шипа. Максимальная ширина пера на них также смещена к острию, но лопасти охватывают большую часть втулки, чем на предыдущем наконечнике (Козенкова, Крупнов 1966, С.85, рис.36:2-3) (Рисунок 1:13-14). По А.И. Мелюковой, они также относятся к отделу І, типу 1, варианту 5, по Т.В. Рябковой - к 5 группе;

3) наконечник стрелы с шипом и асимметрично-ромбической формой пера имеет короткую втулку. Максимальная ширина пера смещена к острию, шип прикреплён в верхней части втулки (Козенкова, Крупнов 1966, С.85, рис.36:1; Ильинская, Тереножкин 1983, С.23, рис.9) (Рисунок 1:35). По А.И. Мелюковой он относится к отделу I, типу 1, варианту 1, по Т.В. Рябковой - к 6 группе (Рябкова 2014, рис. $1: 6)$.

Находки этих стрел очень важны. Их появление в Чечне означает, что скифы проходили мимо горных проходов в Грузии и направлялись к Дербентскому проходу.

Дербент. На вершине Дербентского холма было найдено несколько скифских бронзовых двухлопастных наконечников стрел с ромбической головкой. А.А. Кудрявцев связывает эти наконечники стрел со скифами и датирует их раннескифским периодом (Кудрявцев 1982, С.184, рис. 7:1-3а). Опубликовано пять втульчатых двухлопастных наконечника стрел из Дербента:

1) один двухлопастный наконечник стрелы имеет длинную втулку и шип, прикреплённый в её верхней части (Кудрявцев 1982, рис.7:2) (Рисунок 3:5). По 
А.И. Мелюковой, он относится к отделу І, типу 1, варианту 2 (Мелюкова 1964 табл. V), по Т.В. Рябковой - к группе 1;

2) два двухлопастных наконечника стрел с шипом имеют недлинную втулку (Кудрявцев 1982, рис.7:1, 1а) (Рисунок 3:14-15). По А.И. Мелюковой - отдел I, тип 1, вариант 1, по Т.В. Рябковой - группа 2. Как отмечает Т.В. Рябкова, наконечники этого типа отличаются сравнительно меньшими размерами и более короткой втулкой по сравнению с первой группой (Рябкова 2014, С.380, рис.1:2);

3) наконечник стрелы без шипа и короткой втулкой. Максимальная ширина пера расположена в середине (Кудрявцев 1982, рис.7:3а) (Рисунок 1:11). По А.И. Мелюковой - отдел I, тип 1, вариант 4, по Т.В. Рябковой - группа 5;

4) наконечник стрелы имеет асимметрично-ромбическую головку и шип, прикреплённый в верхней части короткой втулки. Максимальная ширина пера на нём смещена к острию, втулка составляет около 1/4 от общей длины наконечника (Кудрявцев 1982, рис.7:3) (Рисунок 1:36). По А.И. Мелюковой - отдел І, тип 1, вариант 1, по Т.В. Рябковой - группа 6 (Рябкова 2014, рис.1:6).

Все пять наконечников стрел относятся к периоду скифской архаики. Примечательно, что все они относятся к наиболее архаичным скифским наконечникам стрел скифов, поскольку датируются докелермесским периодом.

Апшеронский могильник, Каменный ящик с двухлопастным втульчатым наконечником стрелы. Двухлопастный втульчатый бронзовый наконечник стрелы с асимметрической ромбической головкой и шипом на втулке был найден в каменном ящике на Апшеронском полуострове, в пригороде Баку. Могильное поле, на котором было обнаружено это погребение, располагалось между развалинами древнейшего поселения, называемого местными жителями «Гюрган» или «Эфшеран» и Апшеронским маяком. Из погребений могильника происходила керамика, которую И.М. Джафарзаде относит к ходжалы-кедабекской культуре. Каменный ящик, из которого происходил наконечник стрелы, был ориентирован с запада на восток. В южной половине погребения был найден яйцевидный глиняный серый кувшин с двумя небольшими боковыми ручками, расположенными на широкой части диаметра сосуда. Верхняя часть кувшина лощёная. В западном углу погребения был найден фрагмент красного сосуда грубой работы с тёмно-серой начинкой. К западу от яйцевидного кувшина был найден втульчатый двухлопастный наконечник стрелы и кусок дымчатого обсидиана (Джафарзаде 1948, С.86-87, табл.1:3; 2:1) (Рисунок 2:13; 3:24). Поблизости от них находились три небольших обломка перегнивших трубчатых костей.

И.М. Джафарзаде отмечает, что заострённая часть наконечника стрелы была слегка согнута, что, по его мнению, с одной стороны, может указывать, на то, что стрела вонзилась в тело при сильном ударе и её остриё согнулось. Основываясь на этом, он приходит к выводу, что человек, погребенный в каменном ящике, был убит скифами во время их вторжения в Азербайджан через Дербентский проход в VII в. до н.э. Далее он говорит о возможности того, что изгиб наконечника связан с каким-то ритуалом, и в этом случае, погребённый мог быть представителем скифских племён (Джафарзаде 1948, С.88). И.Н. Алиев считает, что данный наконечник стрелы отражает ранний этап проникновения скифов на Апшерон (Алиев 1992, С.84).

Каменный ящик с рассматриваемым наконечником стрелы был ориентирован с запада на восток. Как отмечает Джафарзаде, эта ориентировка отличалась от ориентации остальных погребений этого могильного поля (Джафарзаде 1948, С.87). Яйцевидные сосуды с узким горлом и небольшими боковыми руч 


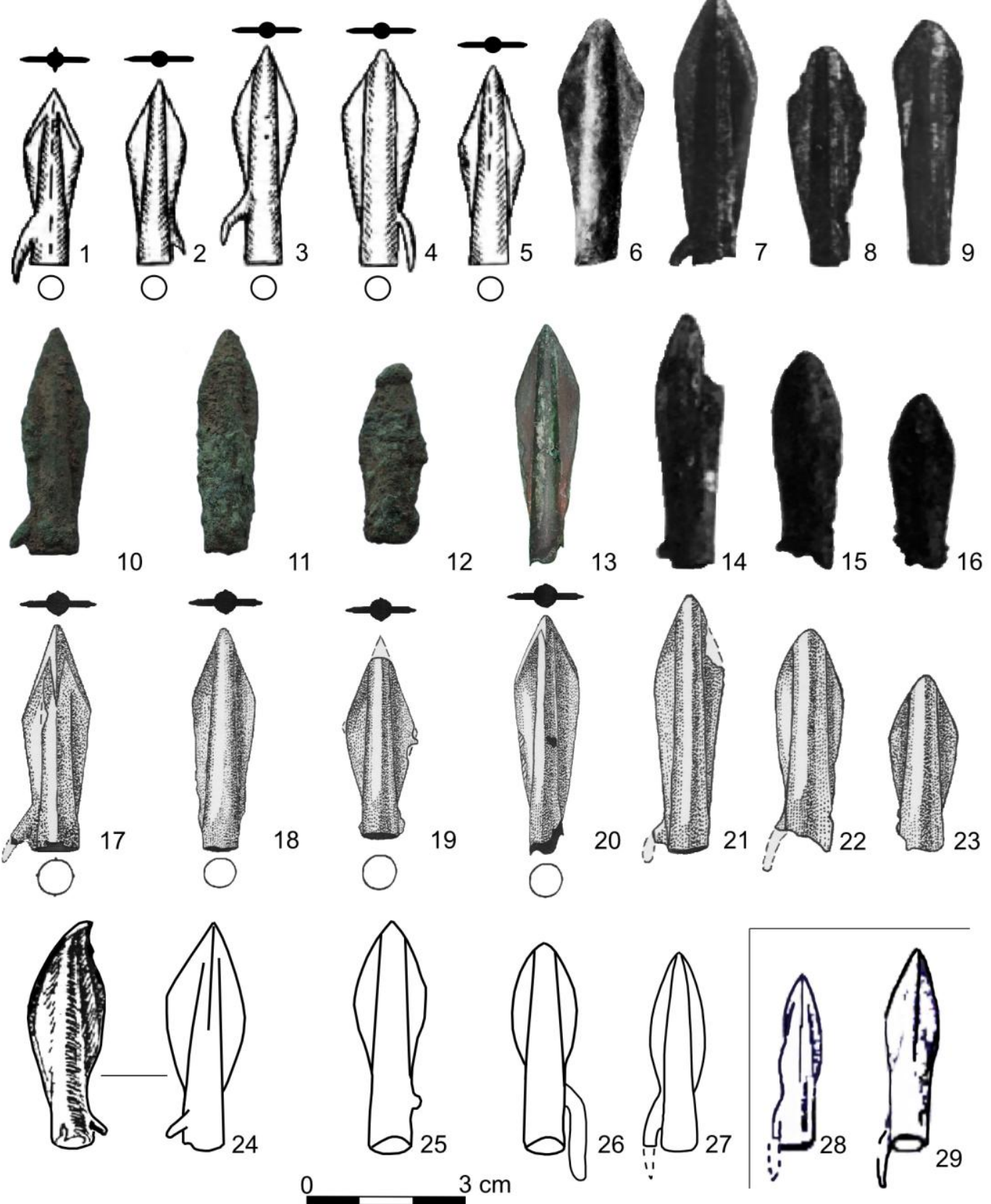

Рисунок 3. Двухлопастные наконечники стрел из Азербайджана, Сержень-Юрта и

Дербента. 1-5 - Дербент; 6-9 - Сержень-Юрт; 10-12 - Шеки, некрополь Йонджалы; 10-11 - погребение в шурфе IV; 12 - погребение в шурфе III; 13 - Физулинский район; 14-16 - Шамкир, некрополь на холме возле карьера суглинок; 17-23 - чертежи наконечников стрел № 10-16; 24 - каменный ящик Апшеронского могильника; 25-26 - Шамкир, с. Кечили; 27 - Мингечаур, грунтовое погребение с вытянутым костяком;

28-29 - Шамкир, Шамхорский могильник. (1-5 - по Кудрявцев 1982: рис. 7: 1-3а;

6-9 - по Козенкова 1965: рис. 24: 6; Козенкова, Крупнов 1966: рис. 36: 1-3; 10-13 - фото: 3. Гасанов; 14-16 - по Кесаманлы, Гусейнова 1980: табл. XIII, Б, 5, 6, 9; 17-23 - чертежи наконечников стрел № 10-16; 24 - по Джафарзаде, 1948: табл. 2: 1; 25-26 - по Кашкай, Селимханов 1973: рис. 15:178; 27 - по Ионе 1953: табл. I, 1, а; 28-29 - не в масштабе, по Асланов 1986: рис. 13) 
ками, расположенными на широкой части диаметра, известны на поселениях Сарытепе и Бабадервиш в Азербайджане (Гусейнова 1989, С.43, табл.26:4042), а также в грунтовых погребениях Мингечаура с вытянутыми костяками. В мингечаурских погребениях подобные сосуды были найдены в ногах погребённых в 50 см от левой ступни или же в юго-восточной части могильной ямы (Ионе 1946, С.400, табл.I:2-5). Джафарзаде следующим образом описывает местоположение яйцевидного кувшина из апшеронского каменного ящика: 1) сосуд располагался в южной части погребения близ боковой стены; 2) к западу от него был найден двухлопастный бронзовый наконечник стрелы и кусок дымчатого обсидиана (Джафарзаде 1948, С.87). Исходя из этих данных, мы приходим к заключению, что сосуд находился в юго-восточной части погребения.

Как пишет О.А. Вишневская, в большинстве случаев «сосуды ставят в ногах погребённых и только в двух в изголовье». В Уйгараке прослеживаются различные формы сосудов, в том числе, один из них - яйцевидный, с невысоким горлом и двумя боковыми вертикальными небольшими ручками на плечиках (Вишневская 1973, С.74-75, рис.45, табл.XXII:21). Некоторые черты этого сосуда, такие как: яйцевидная фрорма, вертикальные ручки, расположенные по сторонам, могут указывать на родственность с сосудом из Апшерона, однако типологически эти сосуды отличаются друг от друга. В других регионах скифросакского мира иногда также фриксируется обряд помещения сосудов в ногах погребённого (Ильинская 1975, С.30, 35, 36, 41, 49, 47). Однако эта черта не является там чёткой спецификой погребального обряда, так, как это прослеживается в Уйгараке и Мингечауре.

Таким образом, Апшеронский каменный ящик с рассматриваемым наконечником стрелы имеет следующие характерные черты: 1) в отличие от остальных каменных ящиков этого могильника он был ориентирован с запада на восток; 2) кувшин из него повторяет по своим формам кувшины из мингечаурских скифоских грунтовых погребений; 3) в мингечаурских скифрских грунтовых погребениях и в каменном ящике из Апшерона сосуды часто находились в юговосточной части захоронений. Как следует из этих наблюдений, некоторые данные указывают на сходные черты обряда и инвентаря мингечаурских скифских грунтовых погребений и анализируемого каменного ящика из Апшерона (Вишневская 1973, С.74-75, рис.45, табл. XXII:21).

Мингечаурские грунтовые погребения с вытянутыми костяками. Погребения с вытянутыми костяками находились в западной части могильного поля Мингечаура. Почти все вытянутые скелеты лежали на спине с ориентировкой головы на северо-запад (Ионе 1946, С.399-400; Казиев 1949, С.20). Подавляющее большинство вытянутых погребений одиночные, лишь некоторые из них парные (Голубкина 1946, могила № 125-126).

Во всех вытянутых погребениях были обнаружены глиняные сосуды. Их количество не превышало 7-8. По цвету, обжигу и отделке керамика погребений представлена различными видами. В большинстве случаев сосуды имели следующее расположение: один большой сосуд находился в ногах погребенного на расстоянии 50 см от левой ступни или в юго-восточной стороне захоронения, другие глиняные сосуды малых размеров находились в области головы (Ионе 1946, С.400).

Из предметов вооружения в захоронениях с вытянутыми костяками были найдены мечи, длинные железные кинжалы, с двусторонним лезвием, железные серповидные ножи, вилы, булавы, копья, втульчатые бронзовые и костяные стрелы, местные южнокавказские стрелы (Ионе 1946, С.402; Казиев 1949, 
С.20-21, рис.22). Преобладающим типом стрел являются бронзовые втульчатые трехлопастные наконечники стрел (Ионе 1946, С.403, табл.ІІІ).

Комплекты украшений, происходящих из погребений с вытянутыми костяками, однотипны. Это одна пара серег-подвесок из золота, серебра и бронзы (Казиев 1949, С.20, рис.14) несколько бронзовых браслетов (не более шести) с украшениями в виде змеиных или животных головок на концах, бронзовые кольца, а также бусы, изготовленные из золота, бронзы, серебра, стекла смальты и цветных камней (в основном, сердолики). Бронзовые зеркала с зооморфными ручками были обнаружены только в двух захоронениях. Найденные в вытянутых могилах бронзовые пластинки в форме девятки иногда располагались при копьях (Ионе 1946, С.400, 402).

В соответствии с Г.И. Ионе, определенная часть вытянутых костяков была погребена на небольшой глубине (1,5 м.) Одновременно с этим Г.И. Ионе отмечает, что над некоторыми костяками была обнаружена темно-коричневая прослойка толщиной до 5 см, со следами трухлявого дерева, что, по его мнению, свидетельствует о наличии деревянного настила (Ионе 1946, С.399-405). Аналогию данного обряда захоронения удалось обнаружить в материалах украинской лесостепи. Исследуя раннескифские курганы бассейна реки Тясмин В.А. Ильинская определила, что погребения в неглубоких грунтовых ямах с деревянным перекрытием относятся к наиболее древним и датируются VII-VI в. до н.э. Она отмечает, что погребения в ямах с деревянными перекрытиями ведут свое происхождение из кочевой степи VIII-VII в. до н.э. (Ильинская 1975, C.80, 87, 92).

Еще одна деталь обряда вытянутых погребений Мингечаура указывает на их связь со скифо-сакским миром периода VII в. до н.э. В 17 грунтовых погребениях Мингечаура с вытянутыми костяками, из 24 исследованных Г.И. Ионе в 1946 г. (70\% от общего числа), сосуды больших размеров были найдены в н огах погребё̈ных в 50 см от левой ступни или же в юго-восточной части могильной ямы. В двух захоронениях вместо них были положены глиняные фрляги. В этих комплексах в изголовье находились сосуды малых размеров и других форм (Ионе 1946, С.400, табл.І:2-5). Как пишет О.А. Вишневская, в большинстве случаев «сосуды ставят в ногах погребённых » (Вишневская 1973, С.74-75, рис.45, табл.XXII:21).

Двухлопастный втульчатый наконечник стрелы происходит из грунтового погребения Мингечаура с вытянутым костяком. Он имеет не ромбическую, а листовидную фрорму пера, длинную втулку и шип, прикреплённый в её верхней части. Втулка несколько короче, чем на шамкирском наконечнике стрелы (Ионе 1953, табл. I:1.а) (Рисунок 2:25). К сожалению, у нас нет информации о том, сколько всего подобных наконечников происходит из Мингечаура. Г.И. Ионе опубликовал только одно из изображений наконечников этого типа. По классифрикации А.И. Мелюковой данный наконечник относится к отделу I, типу 3, варианту 2 (Мелюкова 1964, табл.V).

Эта находка в точности соответствует жаботинской общими размерами, длиной втулки и местом прикрепления шипа. Т.В. Рябкова приводит мнение М.Н. Дараган и В.А. Подобеда о том, что ромбические наконечники стрел могут принимать более сглаженные очертания и напоминать листовидную форму пера благодаря заточке (Рябкова 2014, С.380). Мингечаурские грунтовые погребения с вытянутыми костяками датируются VII-IV вв. до н.э. (Гошкарлы 2014, С.167).

Шамхорский могильник, Шамкир. Чрезвычайный интерес представляют материалы Шамхорского могильника, расположенного в Шамкирском районе на левом берегу реки Куры, на невысоком холме, именуемом «Qara Musanın Yatağ yeri». Раскопки некрополя проводились под руководством Г.Г. Асланова и про- 
должались с 1978 г. по 1983 г. Материалы этого могильника полностью не опубликованы. В нашем распоряжении имеется только информация из работы Г.Г. Асланова (Асланов 1986). В ней есть изображения двух наконечников стрел. В данный момент автору настоящей публикации не удалось обнаружить отчёты о раскопках в архиве Института археологии и этнографии Национальной АН Азербайджана. Краткая информация (без рисунков) из одного отчёта о раскопках 1978 г. содержится в статье С.М. Кашкай: «В Шамхорском районе раскопано десять грунтовых погребений с многоразовыми захоронениями (до девяти) в скорченном положении. В трёх из них, вместе с серо-чёрной керамикой обнаружены железный нож, кинжал и 15 наконечников стрел скифского типа. Один из них листовидной формы, три - подтреугольной фрормы - имели шип на втулке» (Кашкай 2004, С.47).

Более детальная информация приводится в работе Г.Г. Асланова, который приводит следующее описание. Поверхность некрополя была разделена на небольшие прямоугольники мелкими булыжниками, под которыми располагались погребальные камеры на глубине 2,4-3,5 м. Всего были выявлены и исследованы 44 грунтовые могилы. В 25 из них обнаружены одиночные погребения, а в 16 могилах коллективные захоронения - от 2 до 12 костяков. Три могилы оказались кенотафами. Отмечены случаи, когда вместо тела погребённого в погребение укладывали ствол дерева. В могиле №23 был обнаружен антропоморфный деревянный столб.

Г.Г. Асланов пишет, что костяки, в основном, лежали «в полусогнутом положении на правом или левом боку». Ориентировка погребённых не указывается, но отмечается, что она различалась. В могиле №13 на костяке погребённого лежал череп лошади. В погребении №35 был обнаружен полный костяк лошади. Её голова была отрублена и положена сверху на тело погребённого. Человек был положен в 50 см к юго-востоку от обезглавленной лошади. В её черепе найден длинный железный наконечник копья. Асланов считает, что обе лошади (могилы №13 и №35) были принесены в жертву. В могилах было найдено конское снаряжение. Стержневидные трехдырчатые псалии с загнутыми концами и двучастные удила, свитые из двух длинных бронзовых стержней, с круглыми наружными кольцами. Их аналогии известны в скифских мингечаурских курганах и в Малом кургане. Найдены также массивные стержни, покрытые геометрическим орнаментом с петлями на концах (Асланов 1986, рис.14). В погребениях Шамхорского могильника в изголовье многих погребённых находились один или два железных наконечника копья, а у правого или левого виска - по одной серьге или же бронзовые наконечники стрел скифского типа (Асланов 1986, рис.13) (Рисунок 3:28-29). Г.Г. Асланов сообщает: «В другой группе могил обнаружены обожжённые кости животных, глиняные сосуды, покрытые копотью, зола, уголь, следы очага, покрытые охрой скелеты. Иногда отдельные части скелета находились в могиле в разных местах, что свидетельствует о захоронении разрубленного трупа» (Асланов 1986, С.4-5).

Во многих погребениях останки погребённых и инвентарь были «замурованы» толстым слоем жёлтой глины. В некоторых могилах под костяками лежали большие плоские речные камни. В большинстве погребений были найдены плохо обожжённые, закопчённые сосуды с остатками костей птиц, овец и т.д. Асланов отмечает, что иногда вместо костей животных встречаются три мелких круглых речных камня (два белых, один чёрный или наоборот). Один из таких сосудов был найден в кенотафе и содержал два белых и один чёрный камень. Данный обряд приведён в работе Филарха, который пишет: «Скифы перед отходом ко сну берут колчан и, если провели данный день беспечально, опускают 
в колчан белый камушек, а если неудачно - чёрный. При кончине каждого лица выносили колчаны и считали камешки: если белых оказывалось больше, то покойника прославляли как счастливца. Отсюда и произошла пословица, что наш добрый день выходит из колчана» (Зенобий 1948, С.291). Судя по сообщению Филарха, погребённые в Шамхорском могильнике люди с двумя белыми и одним чёрным камнями, считались своими соплеменниками счастливцами. Таким образом, в Шамхорском могильнике зафиксировано отражение скифских религиозных представлений.

Г.Г. Асланов отмечает, что «в Шамхорском могильнике прослеживаются различные погребальные обряды» (Асланов 1986, С.7). Обнаруженные здесь предметы инвентаря разнообразны. Среди них упомянуты глиняные сосуды, модель колеса повозки, пряслица, металлические и костяные украшения, бусы из минералов и египетской пасты, орудия труда, оружие, часть музыкального инструмента и др. Из железных и бронзовых предметов в захоронениях могильника найдены наконечники копий, кинжалы, серпы и ножи, украшения, наконечники стрел скифского типа и конское снаряжение. Привлекает внимание фригура головы быка с треугольной прорезью на лбу и отверстием в нижней части. В области шеи к нему прилегало ещё одно кольцо с отверстиями (Асланов 1986, рис.15). Возможно, это навершие, аналогичное тем, что известны в Венгрии - с быками и треугольными прорезями. К. Бакай считает изделия этого типа скифрскими (Bakay 1971, tabl.I, IV). Наряду с очень красивыми и качественными глиняными сосудами в погребениях встречаются покрытые копотью, грубо формированные, плохо обоженные горшки из глины с примесью песка, крупные хозяйственные кувшины, маслобойки и разнообразные сосуды зооморфных форм. Г.Г. Асланов датирует этот могильник VII-IV вв. до н.э. (Асланов 1986, C.5, 11).

Обряд коллективного погребения со следами огня и захоронение разрубленного костяка - это признаки, специфичные для могильников Южного Приаралья (Сакар-чага 6, Куюсай) конца VIII-VII вв. до н.э. (Яблонский 1996, С.1826, 52, 63-66; Таиров 2007, С.16, 142).

В работе Г.Г. Асланова приводятся рисунки двух наконечников стрел скифского типа из Шамхорского могильника без указания размеров (Асланов 1986, рис.13):

1) Двухлопастный наконечник стрелы, имеет лавролистную фрорму пера, длинную втулку и обломанный шип, прикреплённый, судя по рисунку, в верхней части втулки (Рисунок 3:28). По А.И. Мелюковой изделие относится к отделу 1 , типу 2, варианту 2 (Мелюкова 1964, табл.V).

2) Двухлопастный наконечник стрелы, имеет ромбовидную фрорму пера, длинную втулку и шип, судя по рисунку, прикреплённый в средней части втулки (Рисунок 3:29). По классификации А.И. Мелюковой изделие относится к отделу 1, типу 1, варианту 1 (Мелюкова 1964, табл.V). По классификации Т.В. Рябковой наконечник можно отнести к группе 2 (Рябкова 2014, С.380-381, pис.І.2).

Некрополь Йонджалы в Шеки. Недавно бронзовые двухлопастные наконечники стрел с ромбическим пером были найдены в Шеки. Отметим, что связь топонима Шеки со скифским этнонимом сака уже указывалась (Гейбуллаев 1986, С.27), однако никаких археологических подтверждений этому не было. Впервые свидетельство пребывания скифов в Шеки было обнаружено в 2013 г. в некрополе Йонджалы, который располагается на большом холме на северозападе с.Фазыл. В ходе раскопок под руководством Н. Мухтарова на некрополе было изучено три грунтовых погребения (в шурфах №lII и №/V). В двух из них было обнаружено три втульчатых двухлопастных ромбических наконечника стрелы, один из них с шипом (Рисунок 4). 

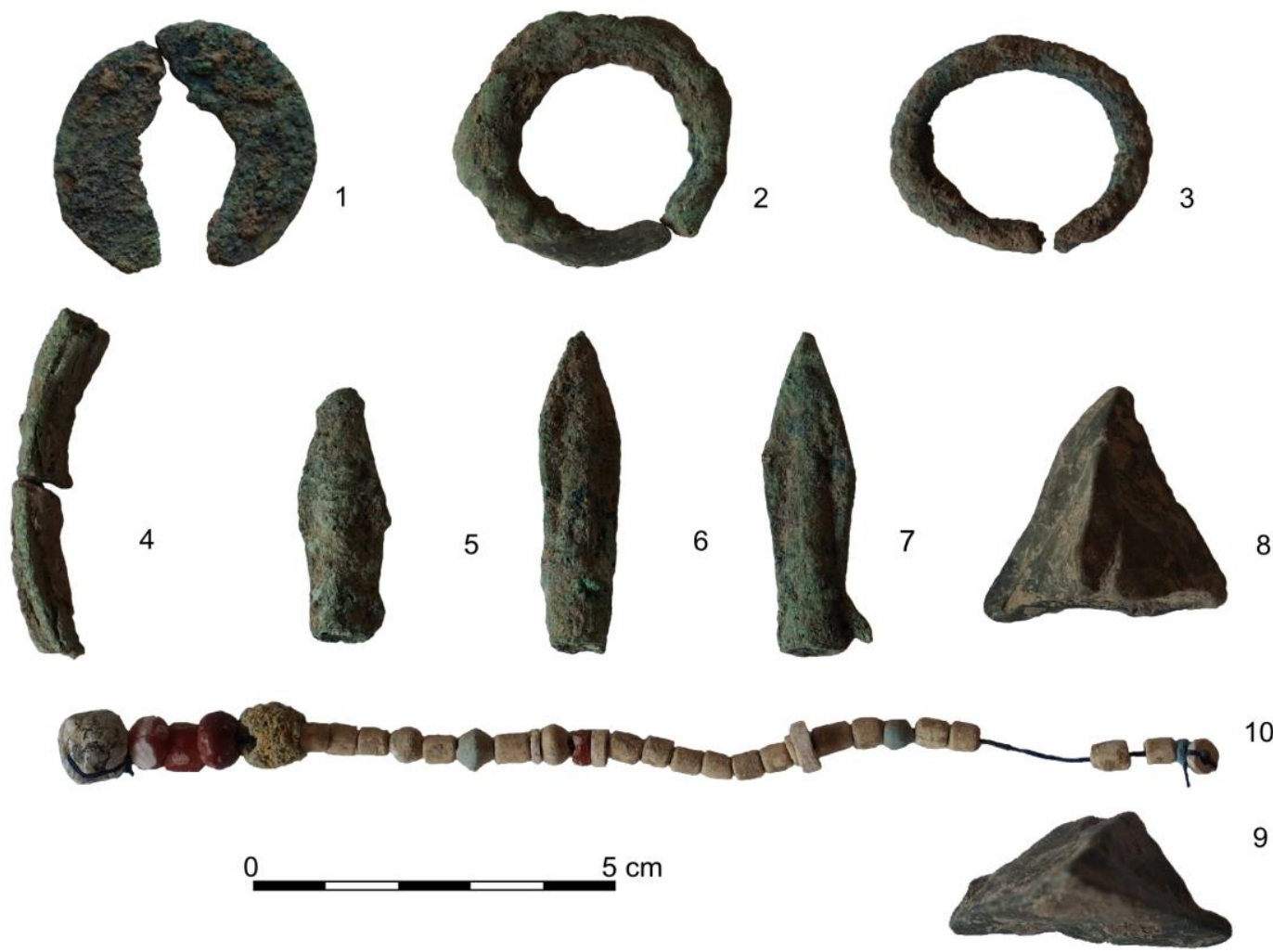

Рисунок 4. Йонджалы в Шеки - некоторые находки из погребений в шурфах III и IV. 1-4 - бронзовые изделия; 5-7 - бронзовые втульчатые наконечники стрел; 8-9 - обломок камня подтреугольной фрормы; 8 - вид сверху, 9 - вид спереди и снизу; 10 - бусы (1-10 - фрото: 3. Гасанов)

По мнению исследователей, расстояние между костяками даёт основание предполагать, что это было коллективное, но, судя по керамическому материалу, разновременное погребение. Основываясь на обнаруженных в шурфе №ІІІ чернолощеной инкрустированной керамики и зооморфных сосудов простых форм, они приходят к выводу, что найденное здесь захоронение относится к более раннему периоду, чем в шурфе №lV. B шурфе №Іll костяк находился в сильно скорченном положении, головой на север, лицом на юго-восток. Вокруг погребённого обнаружено большое количество бронзовых нагрудных и головных украшений, браслет и бусы. Здесь был найден один ромбический двухлопастный наконечник стрелы (Рисунок 4:12; 1:9). В шурфе №lV костяк лежал головой на северо-запад, лицом на юг. Рядом с ним были найдены два наконечника стрелы, один из них с шипом. Судя по фотографии из отчёта, второй наконечник (без шипа) имеет вытянутые пропорции (Рисунок 1:8; 2:12; 3:10,11), (Muxtarov, Bədəlova, Әmrah-qızı 2013, şək.VII:a3). Первый наконечник стрелы был обнаружен впритык к бедренной кости, но не был воткнут в неё, второй находился на расстоянии от него. Археологи, раскопавшие это погребение в шурфе № IV, предполагают, что погребённый был ранен этими наконечниками стрел скифского типа. По устной информации исследователей в захоронениях не было найдено целых черепов и целой керамики.

Примечательно, что в этих погребениях не было обнаружено никаких предметов из железа. Все найденные украшения и скифские наконечники стрел изготовлены из бронзы. Большинство этих изделий имеют аналогии в материа 


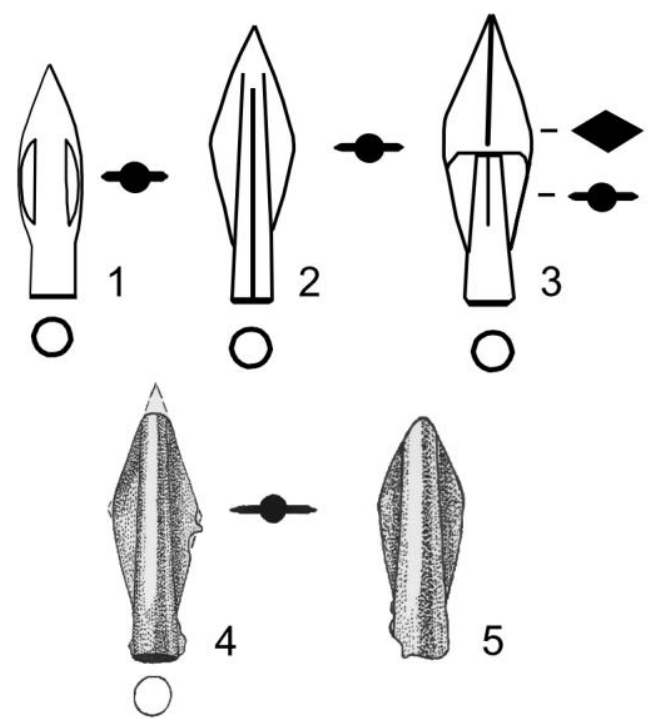

лах ходжалы-кедабекской культуры Азербайджана. Некоторые бронзовые изделия имеют аналогии в соседнем некрополе Тепебаши (Alməmmədov 2006, S.63-74) (Рисунок $3: 1,12)$ и в некрополе на холме возле карьера суглинков в Шамкире (Рисунок 5:9, 10), рассматриваемых ниже. Это бронзовая лунница с отверстием для подвешивания (Рисунок 4:1). Похожие по форме изделия происходят из кургана 23 могильника Сакар-чага 6 в Южном Приаралье (Яблонский 1996, рис.18:8). Лунница из Сакар-чага имеет петлю на оборотной части. Лунницы же из Шамкира и Тепебаши имеют отверстия для подвешивания. На луннице из Йонджалы следов петли не видно, поскольку изделие обломано посередине. Обращает на себя внимание одна очень важная деталь: лунницы из Сакар-чага и из Йон-джалы имеют практически идентичные размеры и пропорции (Рисунок 5:8, 9). В археологии Азербайджана периода поздней бронзы часто встречаются лунницы, однако, в отличие от экземпляров из Шеки и Шамкира, вместо отверстия они снабжены втулкой (Фоменко 1953, С.72, табл.І:3).

Исследователи датируют анализируемые комплексы из некрополя Йонджалы концом VIII-VI в. до н.э. (Muxtarov, Bədəlova, Әmrahqızı 2013, S.23). Все три втульчатых наконечника стрел из этого могильника являются двухлопастными ромбическими. Других типов наконечников здесь нет. Это указывает на то, что данный комплекс следует датировать ранним периодом миграции скифов на Южный Кавказ.

Находка наконечника стрелы возле бедренной кости действительно может свидетельствовать, что погребённый мог быть ранен этой стрелой, но этот вывод несколько спекулятивен. Чтобы установить, явля- 
ются ли погребённые скифами или представителями местного населения, следует привлечь к анализу материалы соседнего некрополя Тепебаши, расположенного на южной окраине с. Фазыл Шекинского района. Заметим, что некрополь Йонджалы, из которого происходят три двухлопастных втульчатых наконечника стрелы, располагается на северо-западе этого же села. Исследователи отмечают, что керамический материал поселений Йонджалы и Тепебаши близок (Muxtarov, Bədəlova, Әmrah-qızı 2013, S.23).
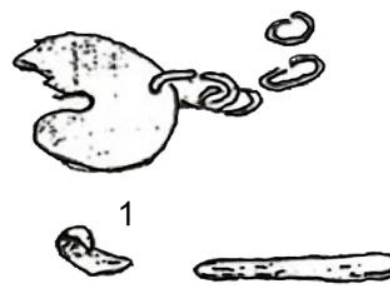
$1 \mathrm{~B}$
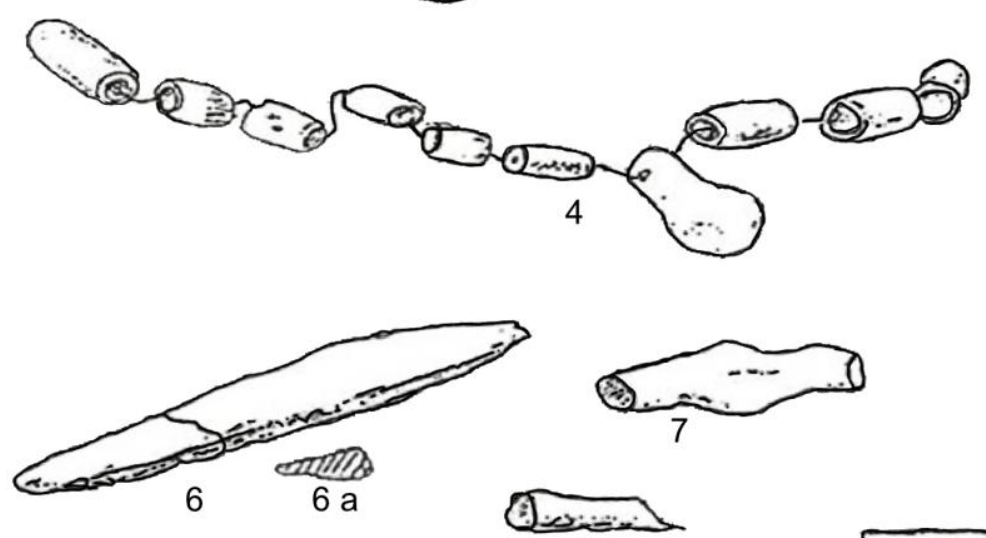

$7 a$

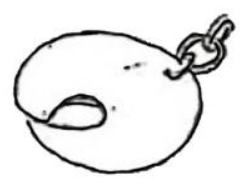

12
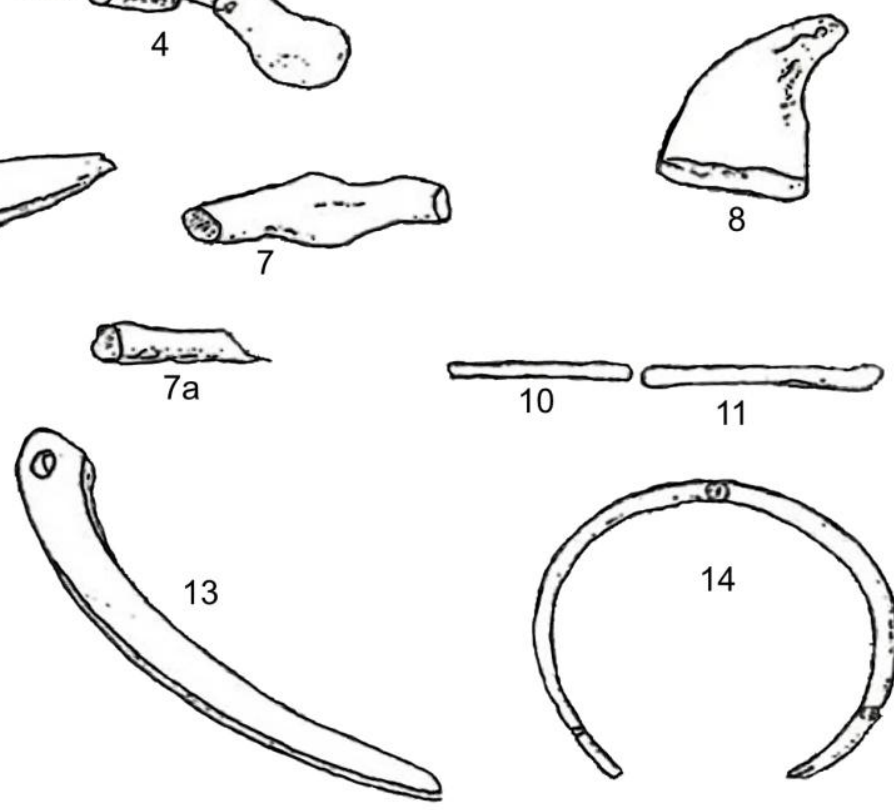

5

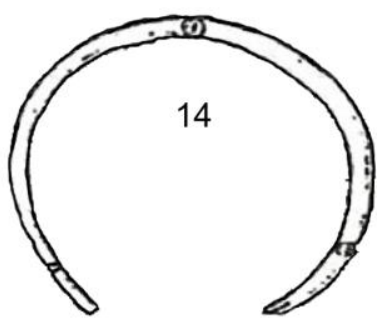

Рисунок 6. Находки из некрополя Тепебаши (по Alməmmədov 2006: tabl. III) 
В некрополе Тепебаши, располагающемся на южной окраине с. Фазыл было раскопано около 20 грунтовых погребений и обнаружено ещё около 20 разрушенных захоронений. Глубина погребений варьировалась - от 45 см до 160 см. Как отмечает X. Алмаммедов, более инвентарные погребения располагались на большей глубине. Спецификой некрополя является ориентировка костяка головой на север, иногда на северо-запад, а в погребении № 3 костяк лежал головой на запад. Большинство костяков сильно или слабо скорчены, некоторые расчленены, один костяк (погребение №2) лежал на спине (Alməm-mədov 2006, S.64).

В погребении №1 обнаружен сильно скорченный костяк, лежавший головой на север-северо-запад. В захоронении обнаружены различные керамические сосуды.

В погребении №2 костяк лежал на спине с согнутыми ногами, руками на груди, головой на север, лицом на юг. В ногах погребённого находился костяк особи мелкого рогатого скота. В захоронении найдены керамические сосуды, содержавшие кости птиц, рыб, кабана и барана. В одном из сосудов находилось лезвие железного ножа. Также были обнаружены наконечник копья, железный кривой нож и украшение типа гривны. Х. Алмаммедов отмечает, что в комплексе зафриксированы угли. Поверх сосудов и под ними отмечен пепел. Алмаммедов предполагает, что этот пепел мог быть специально подсыпан (Alməmmədov 2006, S.65).

В погребении №3 был обнаружен слабо скорченный костяк, лежавший на левом боку, головой на запад. В ногах находились голова и кости кабана.

В погребении №4 находился расчленённый костяк. В восточной части могилы лежала нижняя часть костяка, в северо-западной - верхняя. В центральной части захоронения найдены керамические сосуды и сложенные друг на друга кости человека. В погребении отмечены следы кострища, но следов огня на костях обнаружено не было (Alməmmədov 2006, S.65-66).

Наибольший интерес представляет погребение №9 размерами $120 \times 110$ см и глубиной 160 см. Как отмечает Алмаммедов, это захоронение было совершено по нетипичному для некрополя Тепебаши обряду. Здесь были найдены черепа 20 человек, между которыми были сложены другие человеческие кости. В северной и северо-западной части погребения были уложены черепа четырёх особей крупного рогатого скота и двух особей собаки. Из изделий в погребении был обнаружен только фррагмент черноглиняного сосуда (Alməmmədov 2006, S.67-68).

Алмаммедов датирует это погребение VII в. до н.э. и добавляет, что на некрополе Тепебаши представлены захоронения различных периодов, начиная со «скифского периода» (Alməmmədov 2006, S.69). Г. Гошкарлы датирует некрополь Тепебаши VII-V вв. до н.э. (Гошкарлы 2014, С.166). В большинстве погребений некрополя Тепебаши рассматриваемого нами периода встречаются украшения в виде клыков кабана с отверстиями для подвешивания. Со ссылкой на М. Гусейнову, Х. Алмаммедов отмечает, что кости и клыки кабана встречаются в памятниках конца бронзового и начала железного века Азербайджана. М. Гусейнова связывает это с религиозными воззрениями (Гусейнова 2000, С.17; Alməmmədov 2006, S.65). Л.T. Яблонский указывает, что подвески из клыка кабана «были достаточно характерными для скотоводческих племён восточных степей доскифского и раннескифского времени». Они встречаются в кургане 7 могильника Сакар-чага 6 (Яблонский 1996, рис.14:1), в кургане Аржан в Туве (Gryaznov 1980, рис. 27), в памятниках майэмирской культуры на Алтае, в тагарской культуре (Яблонский 1996, С.46). Золотые изображения кабана были обнаружены в 5-ом Чиликтинском кургане в Казахстане (Черников 1965, табл. XXVIII; Самашев, Ермолаева, Кущ 2008, С.86, 92). Судя по перечисленным па- 
мятникам подобные украшения характерны для памятников XI-VII вB. до н.э. Однако они встречаются и в погребениях более позднего времени. К примеру, в кургане № 11 в Береле. В памятниках Пазырыкского круга вместо самих клыков часто встречаются их деревянные модели (Самашев 2011, С.163, рис.396).

Краниологические исследования пяти сохранившихся черепов из погребения №9 некрополя Тепебаши, проведённые Д.А. Кириченко, позволили установить, что три из них (№1, 4, 5) аналогичны обнаруженным в мингечаурских грунтовых погребениях с вытянутыми костяками. Два других черепа (№2, 3) «обнаруживают сходство с синхронными группами сакских племен с территории Приаралья, Тянь-Шаня и Алтая» (Кириченко 2007, С.258-260, табл.1).

В рассматриваемый период коллективные погребения встречаются в сакских могильниках Сакар-чага в Южном Приаралье (Дашогузский район Туркменистана) - конец VIII-VII вв. до н.э. Однако в Сакар-чага преобладают захоронения с костяками, лежавшими в вытянутом положении на спине, иногда на боку - в скорченном или полускорченном положении. Преимущественная ориентировка погребённых - западная, ориентировка на северо-запад встречается реже. Особенностью этих комплексов являются столбовые конструкции в ямах, сочетание кремации и ингумации, огненный ритуал. Л.Т. Яблонский идентифицирует эти погребения с сакскими племенами (Яблонский 1996, С.18-26, 52; Таиров 2007, С.16; Алексеев 2003, С.142).

Ещё одна группа населения Южного Приаралья, для которых обычны коллективные захоронения - это куюсайская группа. Здесь отмечены захоронения полурасчлененных тел, а также многократные захоронения в одну камеру. Однако огненный ритуал не получил распространения. Л.Т. Яблонский связывает происхождение этих памятников не с саками, а с потомками представителей срубной культуры, продвинувшимися в Центральную Азию из Поволжья (Яблонский 2000, С.66). А.Д. Таиров акцентирует внимание на том, что отличительной чертой сакар-чагской группы сакских памятников является огненный ритуал (Таиров 2007, С.15-16).

Л.Т. Яблонский отмечает, что обряд расчленения, многократного коллективного захоронения и захоронения очищенных костей практиковался на Кавказе с древнейших времён (II тыс. до н.э.) и он не имеет никакого отношения к зороастризму (Яблонский 1996, С.28, 63). Р.М. Мунчаев и К.Ф. Смирнов предполагают, что этот обряд проник в Дагестан с какими-то группами степного населения (Мунчаев, Смирнов 1958, С.159-161, 188). По всей видимости, этот обычай принесли с собой представители срубной культуры. Данный обряд был отмечен Я.И. Гуммелем в курганах №13, 34 и 35 на западе от Гёйгёля (бывш. Ханлар). В курганах №13 и 34 погребённые были расчленены на три части, при этом были разрублены их кости. Курган № 35 имел каменную насыпь: в одной стороне кургана была захоронена голова, в другой - ноги (Гуммель 1940, С.9-10, 31-32, 60). По нашему мнению, эти погребения ходжалы-кедабекской культуры следует связывать с миграцией срубных племён в этот регион (Гасанов 2008). 1

\footnotetext{
${ }^{1}$ В исследуемый период обряд коллективного погребения очень редок для археологии Азербайджана. В научной литературе Азербайджана можно встретить ошибочное указание на распространенность групповых захоронений в период поздней бронзы. Описывая курганы периода поздней бронзы Г.П. Кесаманлы делит их на три группы 1) одиночные; 2) коллективные (или массовые); 3) с деревянной обкладкой. Он пишет о наличии семи курганов с коллективными захоронениями на Хошбулагского яйлаге. Здесь прослеживаются определенные отличия в использовании термина “коллективное захоронение”. Для Южного Приаралья этот термин означает захоронение нескольких человек в одной могиле. Кесаманлы использует термин "коллективное" или "массовое" захоронение, имея в виду наличие нескольких могил под насыпью кургана. Причем в каждой из этих могил было найдено только по одному скелету [Kesemenli 1999, 42 и далее]. Наиболее уникальным является его описание кургана № 3 из Хошбулага. Он называет его "курган с массовым захоронением". В этом кургане было найдено три могилы, две из них кенотафы и лишь в одной был найден скелет (Kesemenli 1999, 59).
} 
Для нас наиболее важно, что в некрополе Тепебаши в Шеки отмечены обе особенности сакар-чагской и куюсайской групп - расчленение тел погребённых и огненный ритуал. Исходя из этого, можно предполагать, что в Азербайджан могли мигрировать обе группы этих племён Южного Приаралья, и уже здесь мог происходить процесс консолидации этих племён с местными племенами Южного Кавказа, многие из которых были родственны племенам куюсайской группы (Гасанов 2008). Этот процесс продолжался несколько веков. Г. Гошкарлы отмечает, что к V-IV вв. до н. э. осевшие в Азербайджане скифы, «постепенно воспринимали местную духовную и материальную культуру, что нашло отражение в изменении поз погребённых» (Гошкарлы 2014, С.168). Дальнейшие антропологические и генетические исследования населения скифского периода в Шеки позволят более детально осветить эту проблему.

В связи с этим приведём мнение Д.С. Гречко, который пришёл к выводу, что аналогии погребальным сооружениям Прикубанья раннескифоского времени следует искать среди сакских погребений Приаралья. При этом он ссылается на Т.В. Рябкову, указавшую ранее на общность погребального обряда в междуречье Дона и Кубани с погребениями Южного Тагискена, Уйгарака и могильника Сакарчага-6 (Рябкова 2003, С.20). Д.С. Гречко пишет: «кочевники из Центральной Азии попадали сперва в Переднюю и Малую Азию. Позже, после походов, они проникают в Предкавказье и Прикубанье, и лишь потом какая-то их часть переселяется в Северное Причерноморье... Часть из них делала это, вероятно, в обход с юга Каспийского моря» (Гречко 2013, С.101). В связи с этим подчеркнём, что в Азербайджане наиболее архаичные двухлопастные наконечники стрел скифов в основном были найдены на севере (Рисунок 7), в предгорьях Кавказа, что указывает на движение мигрантов с севера на юг. Таким образом, их основная масса продвигалась с севера Каспийского моря.

Обратим внимание и на данные топонимики. В обоих топонимах Сакарчага и Шеки присутствует одна и та же основа. В азербайджанской науке топоним Шеки связывают с одним из этнических названий скифов «сака» (Гейбуллаев 1986, С.27). По всей видимости, в данном случае мы имеем дело с миграцией не только археологической культуры, но и древнего этнонима.

Относительно распространения этнонима «сака» заметим, что обычно ареал саков ограничивается Азией. Однако письменные источники не дают оснований для подобных выводов. В Центральной Азии античные письменные источники действительно локализуют такие сакские этнонимы, как амиргийские саки и массагеты. Саков и сакасанов (сакасинов) те же источники локализуют в Анатолии и на Южном Кавказе, племя сагартиев - на Ближнем Востоке, фиссагетов - на востоке европейской части Скифии, сигиннов - в Венгрии (Геродот 1972, I, 201; IV, 22; V, 9; VII, 64; 85; Страбон 1964, XI, 8, 4; Plyni 1942, VI, 28-30). Отметим также, что все скифы себя саками не называли. У каждого из скифских племён было своё этническое название. Некоторые из них содержали основу «сака», как, например, массагеты, сакасины, сигинны и др. Что касается термина «скиф», то он является собирательным названием всех скифских пле-

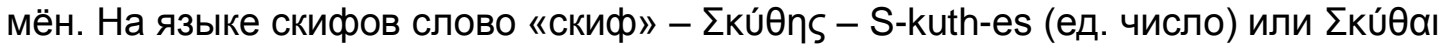
- S-kuth-ai (мн. число), имеет значение «племя». В надписи на серебряной чаше из Иссыкого кургана в Семиречье термин küz (греческое « $\Sigma$ кúӨ»/ассирийское «Ish-kuz») используется как в качестве самоназвания, так и для обозначения соседних племён (Гасанов 2015). Указанные примеры свидетельствуют, что термин «скифр» (-kuz) использовался не только в Европе, но и в Ассирии и Центральной Азии. 


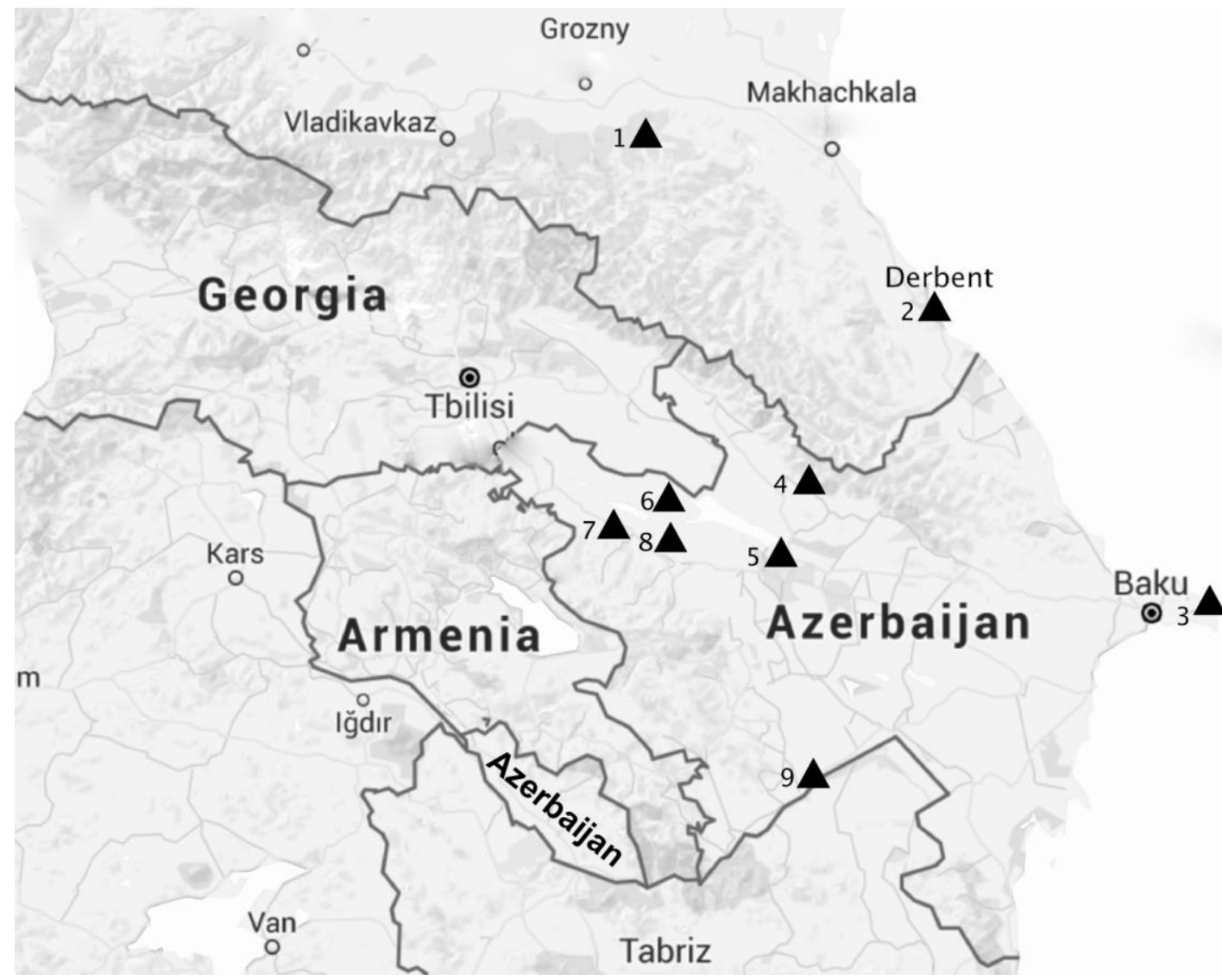

Рисунок 7. Карта распространения двухлопастных наконечников стрел. 1 - Сержень-Юрт; 2 - Дербент; 3 - Апшерон; 4 - Шеки; 5 - Мингечаур; 6 - Шамкир (левый берег Куры); 7, 8 - Шамкир (правый берег Куры); 9 - Физули

Суммируя изложенное, мы можем заключить, что на южной окраине с.Фазыл Шекинского района было найдено коллективное погребение с черепами скифо-саков приаральского происхождения, а на северо-западной окраине этого села были найдены ещё два погребения с двухлопастными ромбическими втульчатыми наконечниками стрел раннескифского типа. Присутствие скифов в этом регионе в качестве местного населения совершенно очевидно. Отсутствие «скифской триады» объясняется, по всей видимости, тем, что скифо-саки, мигрировавшие в Шеки, очень быстро переняли местную материальную культуру.

Теперь перейдём к анализу наконечников стрел из Шеки.

1) Ромбовидный наконечник с шипом, прикреплённым к средней части втулки, и асимметричной головкой из шурфа IV поселения Йонджалы (Рисунок 2:12; 3:10). По классификации А.И. Мелюковой наконечник относится к отделу I, типу 1, варианту 1 (Мелюкова 1964, табл.V). По классификации Т.В. Рябковой он относится к группе 2. Отличительная особенность: меньшие размеры и более короткая втулка, чем у наконечников стрел группы 1; шип прикреплён к средней части втулки.

2) Наконечник стрелы с асимметричной головкой, но без шипа, из шурфа IV. Лопасти практически достигают основания втулки, а максимальная ширина его пера смещена к острию (Рисунок 1:8; 4:11). По классификации А.И. Мелюковой наконечник относится к отделу І, типу 1, варианту 5 (Мелюкова 1964, табл.V). Этот наконечник отличается от того, что изображён на таблице А.И. 
Мелюковой, намного более вытянутыми пропорциями. По классификации Т.В. Рябковой он относится к группе 5. Своими пропорциями и размерами он повторяет образец из Енджи (Рябкова 2014, рис.І.5:8).

3) Наконечник стрелы без шипа из шурфа III (Рисунок 1:9; 3:12). Наконечник небольшой, длиной 3,5 см, остриё пера обломано. По классификации А.И. Мелюковой изделие относится к отделу І, типу 1, варианту 4 (Мелюкова 1964, табл.V). По классификации Т.В. Рябковой наконечник относится к группе 5 . Он отличается от предыдущего экземпляра меньшей длиной и тем, что его максимальная ширина располагается ближе к середине пера. Своими пропорциями он повторяет образец из Дербента (Рябкова 2014, рис. І.5:2), а своими пропорциями и размерами - наконечник стрелы из могилы 5 из с.Полско Косово в Северной Болгарии (Рисунок 1:26), который относится к одним из наиболее ранних (Stantchev 2000, pl. II, 3). Также пропорциями и размерами наконечник стрелы из шурфа III в Шеки очень близок к изделиям из курганов №39 в Уйгараке (Рисунок 3:6) и №20 могильника Сакар-чага 6 (Рисунок 3:2). Однако, длина самого короткого из них составляет 4 см (Яблонский 1996, рис.17: 53, 35: 18, табл.2). По классификации Л.Т. Яблонского эти наконечники стрел входят в категорию I, группу II, отдел Б, тип 4. Это асимметрично-ромбические двухлопастные наконечники стрел с выступающей втулкой, со сплошной прожилкой и нервюрой по всей длине (Яблонский 1996, С.40). Длина самого короткого наконечника стрелы из Уйгарака 4,1 см. У двух из них втулка хорошо выражена и продолжена в виде валика до острия. Судя по рисунку, приведённому в таблице, один из этих наконечников повторяет описанный выше наконечник из Сакар-чага, то есть у него есть прожилка и выделенная нервюра по всей длине (Рисунок 3:6) (Вишневская 1973, С.88-89, табл.XIII:5, 6). По всей видимости, у населения Уйгарака были различные модификации подобных наконечников стрел - симметричные и асимметричные, а их размеры варьировались от $4 \mathrm{~cm}$ до $4,5 \mathrm{~cm}$.

Еще несколько двухлопастных наконечников стрел скифского типа происходят из разграбленного Некрополя, находящегося на холме возле карьера суглинков и из с.Кечили (случайные находки) в Шамкире (Nərimanov, Babayev 1987, S.61; Кашкай, Селимханов 1973, С.103; Кесаманлы, Гусейнова 1980, табл. XIII:Б.5) (Рисунок 1:10, 33-34; Рисунок 2:1, 24; Рисунок 3:21-23, 25-26; Рисунок 8). Двухлопастный наконечник стрелы также был найден в Физули (Гасанов 2017, С.17-50) (Рисунок 3:13, 20).

Выводы. Подытожив, следует отметить, что все наконечники стрел в погребениях некрополя Йонджалы в Шеки являются двухлопастными ромбическими. В погребении из шурфа III периода поздней бронзы, в котором были представлены наиболее ранние типы чернолощёной инкрустированной керамики и зооморфных сосудов, был найден наконечник стрелы с короткой втулкой и без шипа (Рисунок 3:12, 19). Он имеет аналогии в Центральной Азии. В шурфе IV, с материалами более позднего периода, найдено два втульчатых двухлопастных наконечника с короткой втулкой, один из них с шипом (Рисунок 3:10-11, 17-18). Исследователи относят ромбические двухлопастные наконечники без шипов с лопастями, которые охватывают большую часть втулки, к периоду миграции «центральноазиатских кочевников в Причерноморье, Закавказье и Малую Азию» (Рябкова 2014, С.381-383, рис.1.5). То есть наблюдения азербайджанских археологов подтверждаются хронологией двухлопастных наконечников стрел скифов. 

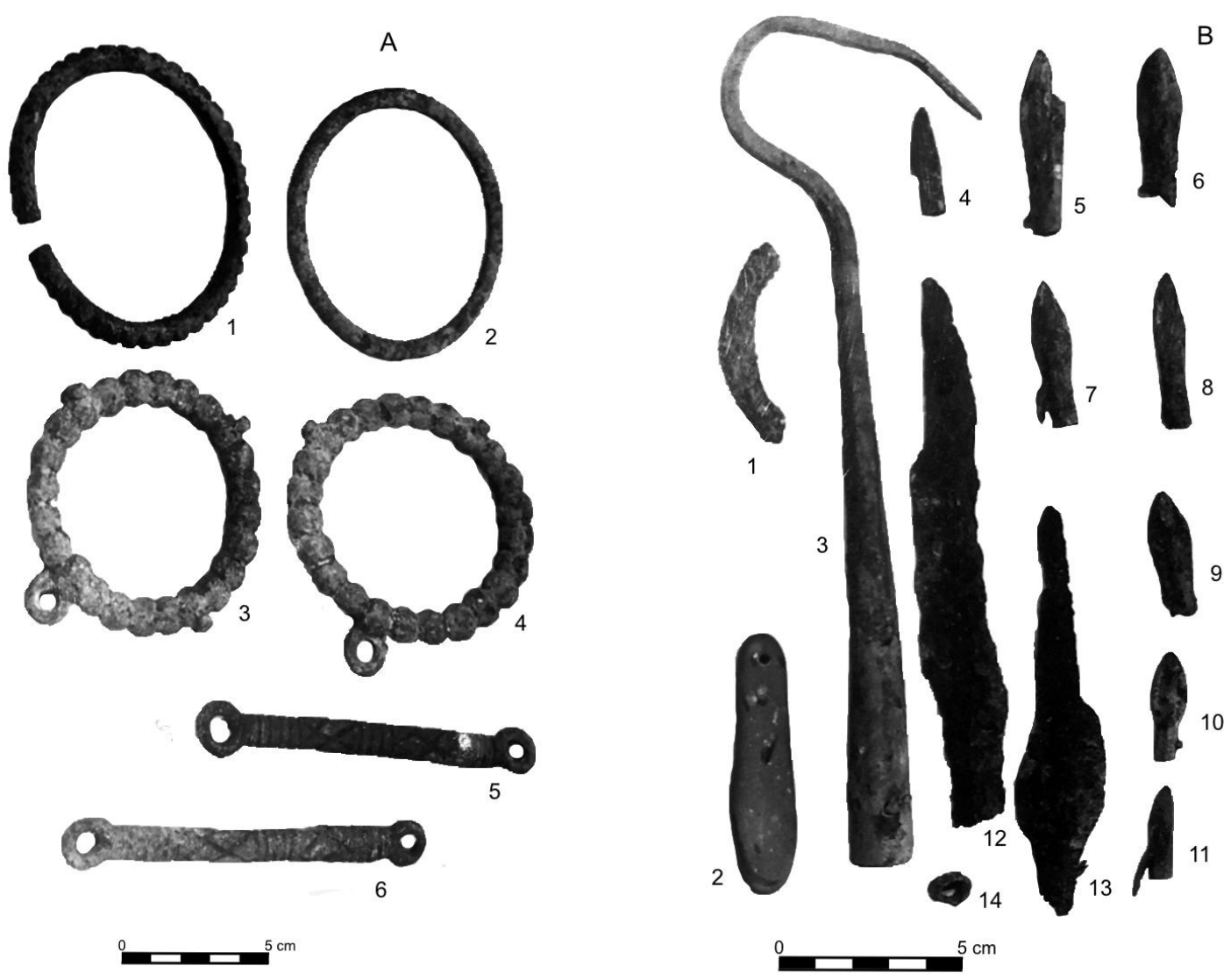

Рисунок 8. Находки с территории некрополя на холме возле карьера суглинок в Шамкире (по Кесаманлы, Гусейнова 1980: табл. XIII: А, Б)

Ещё один вопрос, требующий пристального внимания - проблема совстречаемости наконечников стрел различных типов. А.И. Мелюкова отмечает, что двухлопастные ромбические наконечники с короткой втулкой были широко распространены в VIII-VII вв. до н.э. Они также встречаются в VII-VI вв. до н.э., но в этот период преобладают двухлопастные наконечники стрел с лавролистной или овальной головкой (Мелюкова 1964, С.28, табл.V). О.А. Вишневская относит появление двухлопастных ромбических наконечников с короткой втулкой в Северном Причерноморье к доскифскому периоду. Далее исследователь добавляет, что они распространены в комплексах VII-VI вв. до н.э., где они, как правило, встречаются в единичных экземплярах, и только из наиболее раннего погребения из кургана 524 у с.Жаботин происходит набор таких стрел (Вишневская 1973, С.88-89). Та же ситуация наблюдается с могилой 5 из с. Польско Косово в Северной Болгарии, где все бронзовые наконечники являются двухлопастным ромбическим, с короткой втулкой. Это погребение датируется Д. Станчевым концом VIII - началом VII в. до н.э. (Stantchev 2000, S.35-44). Исходя из этого, можно заключить, что в наиболее ранних комплексах преобладают двухлопастные ромбические наконечники стрел, в то время как в более позднее время они встречаются в единичных экземплярах в комплексах, где преобладают другие наконечники стрел. К.В. Чугунов относительно датировки скифских наконечников стрел замечает: «Совстречаемость разных типов и вариантов обычное явление для колчанных наборов раннескифского времени, и датиров- 
ка комплексов должна основываться даже не на самых поздних типах (нельзя исключить, что они появились раньше, чем мы считаем), а на преобладании того или иного типа» (Чугунов 2011, С.297).

В погребениях некрополя Йонджалы из Шеки все наконечники стрел являются втульчатыми двухлопастными ромбическими. Других типов наконечников здесь нет. Это указывает, что данный комплекс следует датировать ранним периодом миграции скифов на Южный Кавказ. Что касается грунтовых погребений Мингечаура со втульчатыми двухлопастными листовидными наконечниками стрел, то в этих захоронениях преобладают трёхлопастные наконечники, что свидетельствует в пользу их более поздней датировки - VII-VI вв. до н.э.

Находки из некрополя на холме возле карьера суглинков в Шамкире представляют особый интерес. Большинство найденных здесь наконечников стрел двухлопастные (Рисунок 8), что так же, как и в случае с находками из Шеки, указывает на их принадлежность к скифскому архаическому периоду. Дополнительно об этом свидетельствуют находки в Шамкире наконечников, аналогичных тем, что происходят из погребения 1 кургана 2 в Ендже. Здесь же, в Шамкире, в Шамхорском могильнике, отмечен скифо-сакский обряд погребения, архаические стержневидные трёхдырчатые псалии (повторяющие форму жаботинских трехмуфтовых псалий) с двухчастными удилами и два двухлопастных наконечника стрел, в том числе ромбический. Случайные находки двухлопастных стрел в Шамкире также относятся к архаическому времени. Дальнейшее продвижение скифов на Ближний Восток фиксируется находкой двухлопастного ромбического наконечника стрелы в Физули, на границе с Ираном (Рисунок 7).

Для определения того, с кем именно следует связывать эти наконечники стрел в каждом конкретном случае, следует принять во внимание такие факторы, как обряд погребения, сопутствующий археологический материал, топонимы, маршруты миграции и т.д. В случае с наконечниками стрел из СерженьЮрта, Дербента и Апшерона мы однозначно имеем дело со скифами, поскольку данный маршрут подтверждает информацию Геродота о миграции скифов. Помимо этого, находка яйцевидного сосуда с двумя вертикальными боковыми ручками в юго-восточной части Апшеронского погребения свидетельствует в пользу скифского обряда и имеет аналогии в Уйгараке.

В случае с находками из Мингечаура и Шамкира мы также сталкиваемся со скифским обрядом или сопутствующими скифскими изделиями, а именно, трёхлопастными наконечниками стрел. В случае с двухлопастным наконечником стрелы из Физули определить его происхождение сложно, поскольку в этом регионе не было найдено погребений со скифскими изделиями. Однако здесь были найдены трёхлопастные наконечники стрел архаических типов. Что касается наконечников стрел из некрополя Йонджалы в Шеки, то топонимические данные указывают на присутствие здесь саков. Археологические материалы соседнего некрополя Тепебаши свидетельствуют о наличии здесь обряда погребения, повторяющего обряд Сакар-чага и Куюсая в Южном Приаралье, а антропологические материалы некрополя Тепебаши указывают на наличие здесь мигрантов из Приаралья.

\section{Әдебиеттер тізімі/ Список литературы}

1. Алексеев А.Ю. Хронография Европейской Скифии VII-IV веков до н.э. - СПб.: Гос. Эрмитаж, 2003. -416 c.

2. Алиев И.Н. Абшерон в эпоху бронзы и раннего железа: Дис. ...канд. ист. наук. - Баку, 1992, 135 с.

3. Асланов Г. Г. Шамхорский могильник. - Баку: Элм, 1986. - 11 с. 
4. Вишневская О.А. Культура сакских племен низовьев Сырдарьи в VII-V вв. до н.э.: по материалам Уйгарака. - М.: Наука, 1973. - 160 с.

5. Галанина Л.К. Келермесские курганы: Царские погребения раннескифской эпохи. (Степные народы Евразии т. 1.) - М.: Палеограф, 1997. - 316 с.

6. Гасанов З.Г. Иссыкская посвятительная надпись // Эпиграфрика Востока. - М.: Институт востоковедения РАН, 2015. - Вып. 31. - С.34-59.

7. Гасанов З.Г. Киммерийцы и их место в истории Азербайджана: Автореф. дис. ... канд. ист. наук. - Баку, 2008. - 48 с.

8. Гасанов 3.Г. Архаические наконечники стрел скифского типа в восточной части Кавказа: проблема миграции скифов // Stratum Plus. - 2017. - №3. - C.17-50.

9. Гасанов 3.Г. Погребальный обряд как основа выявления собственно скифских курганов Азербайджана. B:W. Blajer \& (ред.). Peregrinationes archaeologicae in Asia et Europa: Joanni Chochorowski dedicatae. - Krakow: Instytut Archeologii Uniwersytetu Jagiellońskiego, Profil-Archeo, 2012. C.519-527.

10. Гейбуллаев Г.А. Топонимия Азербайджана: историко-этнографическое исследование. - Баку: Элм, 1986.

11. Геродот. История. Пер. Стратановского Г.А. - Л.: Наука, 1972. - 600 с.

12. Голубкина Т.И. Описание могил могильного поля городища №1 археологических раскопок в Мингечауре. Август-Сентябрь 1946 г. AMEA Arxeologiya və Etnoqrafiya İnstitutunun arxivi: İnv. № 4849, 1946.

13. Гошкарлы Г. Скифская тематика в историко-археологической литературе Азербайджана // Гілея: науковий вісник. - 2014. - Вып.91. - С.165-169.

14. Гречко Д.С. О происхождении погребальных сооружений Прикубанья раннескифского врем ени. Шестая международная кубанская археологическая конференция. - Краснодар: Экоинвест, 2013. - С.99-102.

15. Грязнов М.П. Аржан. Царский курган раннескифского времени. - Л.: Наука, 1980. - 62 с.

16. Гуммель Я.И. Археологические очерки. - Баку: АзФАН, 1940. - 166 с.

17. Гусейнова М.А. Керамика Восточного Закавказья эпохи поздней бронзы и раннего железа (XIV-IX вв. до н.э.). - Баку: Элм, 1989. - 128 с.

18. Гусейнова М. Предметы культа и символы власти в памятниках материальной культуры Азербайджана эпохи поздней бронзы и раннего железа. // Azərbaycan arxeologiyası. - 2000. - №3-4. C.14-22.

19. Дараган М.Н. Начало раннего железного века в Днепровской Правобережной лесостепи. Киев: КНТ, 2011. - 829 с.

20. Джафарзаде И.М. Археологические разведки на Апшероне // Azərbaycan SSR EA xəbərləri. 1948. - № 6. - С.81-95.

21. Есаян С.А., Погребова М.Н. Скифские памятники Закавказья. - М.: Наука, 1985. - 152 с.

22. Зенобий. Сокращение из [сборников] пословиц [Лукилла] Таррейского и Дидима, составленное в алфравитном порядке // Вестник древней истории. - 1948. - №4. - С. 289-291.

23. Ильинская В.А. Раннескифские курганы бассейна р. Тясмин (VII-VI вВ. до н.э.). - Киев: Наукова думка, 1975. - 223 с.

24. Ильинская В.А., Тереножкин А.И. Скифия VII—IV вв. до н.э. - Киев: Наукова думка, 1983. - 379 с.

25. Ионе Г. И. Археологические раскопки в Мингечауре: некоторые данные к вопросу о датировке грунтовых погребений // Доклады АН Азербайджанской ССР. - 1946. - №9. - Т.2. - С.399-405.

26. Ионе Г.И. Мингечаурская разновидность наконечников стрел «скифского» типа. // АММ, III, Баку, 1953. - С.81-97.

27. Исмагилов Р.Б. Погребение Большого Гумаровского кургана в Южном Приуралье и проблема происхождения скифской культуры. // АСГЭ. - 1988. - Вып.29. - С.29-47.

28. Казиев С.М. Археологические раскопки в Мингечауре // Azərbaycan Maddi Mədıniyyəti. - Bakı, 1949. - T.I. - C.9-49.

29. Кашкай М.А. Селимханов И.Р. Из истории древней металлургии Кавказа. - Баку: Элм, 1973. $223 \mathrm{c}$.

30. Кашкай С.М. О скифских походах через Кавказ на Ближний Восток // İ.əliyevin 80 illiyinə həsr olunmuş Elmi konfransın materialları, 12 Mart, 2004. - Bakı: Elm, 2004. - C.41-52.

31. Кесаманлы Г.П. Археологические памятники эпохи бронзы и раннего железа Дашкесанского района. - Баку: Ağrıdağ, 1999. - 179 с.

32. Кесаманлы Г.П., Гусейнова М.А. Отчет первого отряда шамхорской археологической экспедиции за 1980 г. AMEA Arxeologiya vә Etnografiya İnstitutunun elmi arxivi: İnv. № h-260, - Баку, 1980. 14 с. + XV табл.

33. Кириченко Д. Новые материалы к палеоантропологии Азербайджана // Tarix və onun problemləri. - 2007. - №1. - С.258-260.

34. Козенкова В.И. Исследования Сержень-Юртовского поселения в 1963 г. // Краткие сообщения Института археологии. - 1965. - Вып.103. - С.67-74. 
35. Козенкова В.И., Крупнов Е.И. Исследования Сержень-Юртовского поселения. По раскопкам 1964 г. // Краткие сообщения Института археологии. - 1966. - Вып.106. - С.81-87.

36. Кудрявцев А.А. О новой хронологии древнего Дербента. // Советская археология. - 1982. №4. - С.165-186.

37. Махортых С. Об одной группе раннескифских памятников Днепровского лесостепного Правобережья // Revista Arheologica. - 2014. - Vol.X. - N1-2. - C.69-78.

38. Мелюкова А.И. Вооружение скифов. - М.: Наука, 1964. - 90 с.

39. Мунчаев Р.М., Смирнов К.Ф. Археологические памятники близ сел. Карабудахкент // Материалы и исследования по археологии СССР. - 1958. - № 68. - 196 с.

40. Ольховский В.С. Скифская триада // Памятники предскифского и скифского времени на юге Восточной Европы. Материалы и исследования по археологии России. - 1997. - №1. - С.85-96.

41. Полін, С.В. Хронологія ранньоскіфрських пам'яток. // Археологія. - 1987. - № 59. - С.17-36.

42. Рябкова Т.В. Курган 524 у с. Жаботин в системе памятников периода скифской архаики // Российский археологический ежегодник. - 2014. - Вып.4. - С.372-432.

43. Рябкова Т.В. Раннескифские памятники Нижнего Подонья и Прикубанья: Автореф. дис. ... канд. ист. наук. - СПб., 2003. - 24 с.

44. Самашев 3. Берель. - Алматы: Таймас, 2011. - 236 с.

45. Самашев 3., Ермолаева А., Кущ Г. Древние сокровища казахского Алтая. - Алматы: Öner, 2008. -200 c.

46. Скорый С.А. Скифы в Днепровской Правобережной лесостепи. - Киев: б.и, 2003. - 161 с.

47. Страбон. География: в 17 книгах. / Пер. Стратановского Г. А. - Л.: Наука, 1964. - 944 с.

48. Таиров А.Д. Кочевники Урало-Казахстанских степей в VII-VI вB. до н.э. - Челябинск: Изд-во ЮУрГУ, 2007, - 274 с.

49. Фоменко В.П. Грунтовое погребение № 63 в Мингечауре // Azərbaycan Maddi Mədıniyyəti. Bakı, 1953. - III. - C.67-80.

50. Хохоровский Я. Экологический «стресс» в Западной Сибири в «культурный шок» в Карпатской котловине в конце бронзового века // Международный симпозиум «Terra Scythica», 17-23 августа 2011 г. Денисова Пещера, Алтай. - Новосибирск: Институт археологии и этнографии СО РАН, 2011. - С.9-10.

51. Черников, С.С. Загадка Золотого кургана. Где и когда зародилось «скифрское искусство». - М.: Наука, 1965. - 190 с.

52. Чугунов К.В. Аржан-2, реконструкция этапов функционирования погребально -поминального комплекса и некоторые вопросы его хронологии // Российский археологический ежегодник . СПб, 2011. - Вып.1. - С.262-335.

53. Яблонский Л.Т. Главные миграционные процессы на территории Южного Приаралья в раннем железном веке // Нижневолжский археологический вестник. - 2000. - Вып.3. - С.64-83.

54. Яблонский Л.Т. Саки Южного Приаралья (Археология и антропология могильников). - М.: ИА PAH 1996. - $186 \mathrm{c}$.

55. Alməmmədov X. Təpəbaşı nekropolu // Azərbaycan arxeologiyası. - 2006. - VIII. - №1-4. - S.63-74.

56. Bakay Kornel. Scythian Rattles in the Carpathian Basin and their Eastern Connections. - Budapest: Akademiai Kiado, 1971. - 131 p.

57. Muxtarov N., Bədəlova İ., Omrah-qızı C. Şəki Arxeologiya və Folklor qrupunun, Şəki-Qax-Oğuz arxeoloji ekspedisiyasının 2013-cü ildə gördüyü işlərin geniş Hesabatı. Şəki-Bakı: AMEA Arxeologiya və Etnoqrafiya İnstitutunun arxivi: İnv. № - 777, 2013, 64 s. + 67 tabl.

58. Nərimanov I.H., Babayev I.A. Keçilidə arxeoloji tapıntılar // Azərbaycan Maddi Mədıniyyəti. - Bakı, 1987. - X. - S.57-68.

59. Plyni. Natural History. - Volume II./ trans. by Rackham H. - Cambridge: Harvard University Press, 1942. $-663 \mathrm{p}$.

60. Stantchev Dimitar. Warrior Burial in the Lower Course of the Yantra // Tombes tumulaires de l' Age du Fer dans le Sud-Est de l'Europe. - 2000. - N1. - P.35-44.

\section{Reference}

Alekseev 2003 - Alekseev, AYu 2003, Hronografiya Evropejskoj Skifii VII-IV vekov do n.eh, Gos. EHrmitazh, Saint-Petrsburg, 416 s. (Alekseev, AYu 2003, Chronography of European Scythia VIIIV centuries BC, State EHrmitazh, Saint-Petrsburg, 416 p). (in Rus).

Aliev 1992 - Aliev, IN 1992, Absheron v ehpohu bronzy $i$ rannego zheleza: Dis. ...kand. ist. Nauk, Baku, 135 s. (Aliev, IN 1992, Abseron in the bronze age and early iron: Dis. ... kand.east. sciences', Baku, 135 p). (in Rus).

Alməmmədov 1971 - Alməmmədov, X 1971, Təpəbaşı nekropolu, Azərbaycan arxeologiyası, VIII, №14, S.63-74. (Alməmmədov, X 1971, Təpəbaşı nekropolu, Azərbaycan arxeologiyası, VIII, №1-4, S.63-74). (in Azerb). 
Aslanov 1996 - Aslanov, GG 1996, SHamhorskij mogil'nik, Ehlm, Baku, 11 p. (Aslanov, GG 1996, Shamkhor burial ground, Ehlm, Baku, 11 p). (in Rus).

Bakay Kornel 1971 - Bakay Kornel, Scythian Rattles in the Carpathian Basin and their Eastern Connections, Akademiai Kiado, Budapest, 131 p. (Bakay Kornel, Scythian Rattles in the Carpathian Basin and their Eastern Connections, Akademiai Kiado, Budapest, 131 p). (in Eng).

Galanina 1997 - Galanina, LK 1997, Kelermesskie kurgany: Carskie pogrebeniya ranneskifskoj ehpohi. (Stepnye narody Evrazii t. 1.), Paleograf, Moscow, 316 s. (Galanina, LK 1997, Kelermess mounds: Royal burials of the early Scythian epoch. (Steppe peoples of Eurasia t. 1.), Paleograf, Moscow, 316 p). (in Rus).

Gasanov 2015 - Gasanov, ZG 2015, Issykskaya posvyatitel'naya nadpis', EHpigrafika Vostoka, Institut vostokovedeniya RAN, Moscow, Vyp. 31, S.34-59. (Gasanov, ZG 2015, Issykskaya dedicatory inscription, Epigraphy of the East, Institut East studies, RAS, Moscow, Issue 31, S.34-59). (in Rus).

Gasanov 2008 - Gasanov, ZG 2008, Kimmerijcy $i$ ih mesto v istorii Azerbajdzhana: Avtoref. dis. ... kand. ist. Nauk, Baku, 48 s. (Gasanov, ZG 2008, Cimmerians and their place in the history of Azerbaijan: author. dis. ... kand. east. sciences, Baku, 48 p). (in Rus).

Gasanov 2017 - Gasanov, ZG 2017, Arhaicheskie nakonechniki strel skifskogo tipa v vostochnoj chasti Kavkaza: problema migracii skifov, Stratum Plus, №3, S.17-50. (Gasanov, ZG 2017, Archaic arrowheads of the Scythian type in the Eastern part of the Caucasus: the problem of migration of Scythians, Stratum Plus, №3, P.17-50). (in Rus).

Gasanov 2012 - Gasanov, ZG 2012, Pogrebal'nyj obryad kak osnova vyyavleniya sobstvenno skifskih kurganov Azerbajdzhana. V:W. Blajer \& (red.). Peregrinationes archaeologicae in Asia et Europa: Joanni Cho-chorowski dedicatae, Instytut Archeologii Uniwersytetu Jagiellońskiego, Profil-Archeo, Krakow, 2012, S.519-527. (Gasanov, ZG 2012, Funeral rites as the basis of identifying the actual Scythian burial mounds of Azerbaijan. In: W. Blajer \& (EDS.). Peregrinationes archaeologicae in Asia et Oceania: Joanni Cho-chorowski dedicatae, V:W. Blajer \& (red.). Peregrinationes archaeologicae in Asia et Europa: Joanni Cho-chorowski dedicatae, Instytut Archeologii Uniwersytetu Jagiellońskiego, Profil-Archeo, Krakow, 2012, P.519-527). (in Rus).

Gejbullaev 1986 - Gejbullaev, GA 1986, Toponimiya Azerbajdzhana: istoriko-ehtnograficheskoe issledovanie, EHIm, Baku. (Gejbullaev, GA 1986, Toponymy of Azerbaijan: historical and ethnographic research, EHIm, Baku). (in Rus).

Gerodot 1972 - Gerodot 1972, Istoriya. Per. Stratanovskogo G.A, Nauka, Leningrad, 600 s. (Herodotus 1972, History, Transl. Stratanovskogo G.A, Nauka, Leningrad, 600 s). (in Rus).

CHernikov 1965 - CHernikov, SS 1965, Zagadka Zolotogo kurgana. Gde i kogda zarodilos' "skifskoe iskusstvo", Nauka, Moscow, 190 s. (CHernikov, SS 1965, The mystery of the Golden mound. Where and when was born "Scythian art", Nauka, Moscow, 190 s). (in Rus).

CHugunov 2011 - Chugunov, KV 2011, Arzhan-2, rekonstrukciya ehtapov funkcionirovaniya pogrebal'no-pominal'nogo kompleksa i nekotorye voprosy ego hronologii, RossiīskiI arheologicheskil ezhegodnik, Saint-Petersburg, Vyp.1, S.262-335. (Chugunov, KV 2011, . Arzhan2 , reconstruction of stages of functioning of the funeral and memorial complex and some questions of its chronology, Russian archaeological Yearbook, Saint-Petersburg, Vyp.1, S.262335). (in Rus).

Golubkina 1946 - Golubkina, TI 1946, Opisanie mogil mogil'nogo polya gorodishcha №1 arheologicheskih raskopok v Mingechaure. Avgust-Sentyabr' 1946 g., AMEA Arxeologiya və Etnoqrafiya Institutunun arxivi: Inv. № 4849. (Golubkina, TI 1946, Description of the graves of the burial fields of the ancient settlement No. 1 archeological digs in Mingachevir. August-September 1946: Inv. No. 4849,, AMEA Arxeologiya və Etnoqrafiya Institutunun arxivi: Inv. № 4849). (in Rus).

Goshkarly 2014 - Goshkarly, G 2014, Skifskaya tematika v istoriko-arheologicheskoj literature Azerbajdzhana, Gileya: naukovij visnik, Vyp.91, S.165-169. (Goshkarly, G 2014, Scythian themes in historical and archaeological literature in Azerbaijan, Gileya: naukovij visnik, Vyp.91, P.165169). (in Rus).

Grechko 2013 - Grechko, DS 2013, O proiskhozhdenii pogrebal 'nyh sooruzheniǐ Prikuban'ya ranneskifskogo vremeni, SHestaya mezhdunarodnaya kubanskaya arheologicheskaya konferenciya, EHkoin-vest, Krasnodar, S.99-102. (Grechko, DS 2013, On the origin of the funeral constructions of the Kuban' area of the early Scythian time. Sixth international Kuban archaeological conference, SHestaya mezhdunarodnaya kubanskaya arheologicheskaya konferenciya, EHkoin-vest, Krasnodar, S.99-102). (in Rus).

Gryaznov 1980 - Gryaznov, MP 1980, Arzhan. Carskij kurgan ranneskifskogo vremeni, Nauka, Leningrad, 1980, 62 s. (Gryaznov, MP 1980, Arzhan. Royal Kurgan of the early Scythian time, Nauka, Leningrad, 1980, 62p.). (in Rus).

Gummel' 1940 - Gummel', Yal 1940, Arheologicheskie ocherki, AzFAN, Baku, 166 s. (Gummel', Yal 1940, Archaeological essays, AzFAN, Baku, 166 s). (in Rus).

Gusejnova 1989 - Gusejnova, MA 1989, Keramika Vostochnogo Zakavkaz'ya ehpohi pozdnej bronzy $i$ rannego zheleza (XIV-IX vv. do n.eh.), EHlm, Baku, 128 s. (Gusejnova, MA 1989, Ceramics of 
Eastern Caucasus of the late bronze age and early iron age (XIV-IX centuries BC), EHIm, Baku, $128 \mathrm{~s})$. (in Rus).

Gusejnova 2000 - Gusejnova, M 2000, Predmety kul'ta i simvoly vlasti v pamyatnikah material'noj kul'tury Azerbajdzhana ehpohi pozdnej bronzy i rannego zheleza, Azərbaycan arxeologiyası, №34, P.14-22. (Gusejnova, M 2000, The cult Objects and symbols of power in the monuments of material culture of Azerbaijan of late bronze and early iron epoch, Azərbaycan arxeologiyası, №34, P.14-22). (in Rus).

Daragan 2011 - Daragan, MN 2011, Nachalo rannego zheleznogo veka v Dneprovskoj Pravoberezhnoj lesostepi, KNT, Kiev, 829 s. (Daragan, MN 2011, The beginning of the early iron age in the Dnieper right Bank forest-steppe, KNT, Kiev, 829 p). (in Rus).

Dzhafarzade 1948 - Dzhafarzade, IM 1948, Arheologicheskie razvedki na Apsherone, Azərbaycan SSR EA xəbərləri, № 6, S.81-95. (Dzhafarzade, IM 1948, Archaeological exploration on the Absheron Peninsula, Azərbaycan SSR EA xəbərləri, № 6, P.81-95). (in Rus).

Esayan 1985 - Esayan, SA, Pogrebova, MN 1985, Skifskie pamyatniki Zakavkaz'ya, Nauka, Moscow, 152 s. (Esayan, SA, Pogrebova, MN 1985, The Scythian monuments of Transcaucasia, Nauka, Moscow, 152 p). (in Rus).

Fomenko 1953 - Fomenko, VP 1953, Ground burial № 63 in Mingechaur, Azərbaycan Maddi Mədıniyyətii,Bakı, III, S.67-80. (Fomenko, VP 1953, Gruntovoe pogrebenie № 63 v Mingechaure, Azərbaycan Maddi Mədıniyyətii,Bakı, III, S.67-80). (in Rus).

Hohorovskij 2011 - Hohorovskij, YA 2011, EHkologicheskij «stress» v Zapadnoj Sibiri v «kul'turnyj shok» v Karpat-skoj kotlovine v konce bronzovogo veka, Mezhdunarodnyj simpozium «Terra Scythica», 17-23 avgusta $2011 \mathrm{~g}$. Denisova Peshchera, Altaj, Institut arheologii i ehtnografii SO RAN, Novosibirsk, S.9-10. (Hohorovskij, YA 2011, Ecological "stress"I n Western Siberia in the" cultural shock "in the Carpathian basin at the end of the bronze age, International Symposium" Terra Scythica", August 17-23, 2011 Denisova Cave, Altai, Institut arheologii i ehtnografii SO RAN, Novosibirsk, S.9-10). (in Rus).

Il'inskaya 1975 - Il'inskaya, VA 1975, Ranneskifskie kurgany basseĭna r. Tyasmin (VII-VI vv. do n.eh.), Nauko-va dumka, Kiev, 223 s. (Il'inskaya, VA 1975, The early Scythian barrows of the basin of the Tyasmin (VII-VI centuries BC)), Nauko-va dumka, Kiev, 223 p). (in Rus).

Il'inskaya 1983 - Il'inskaya, VA, Terenozhkin, Al 1983, Skifiya VII-IV vv. do n.eh, Naukova dumka, Kiev, 379 s. (II'inskaya, VA, Terenozhkin, Al 1983, Scythia VII - IV centuries BC, Naukova dumka, Kiev: 1983, 379 s). (in Rus).

Ione 1946 - lone, GI 1946, Arheologicheskie raskopki v Mingechaure: nekotorye dannye k voprosu o datirov-ke gruntovyh pogrebenij, Doklady AN Azerbajdzhanskoj SSR, №9, T.2, S.399-405. (Ione, GI 1946, Archaeological excavations in Mingechaur: some data on the dates of underground burials, Reports of the Academy of Sciences of the Azerbaijan SSR, №9, T.2, S.399-405). (in Rus).

lone 1953 - lone, Gl 1953, Mingechaurskaya raznovidnost' nakonechnikov strel "skifskogo» tipa, AMM, III, Baku, S.81-97. (Ione, GI 1953, Mingechaur variety of arrowheads "Scythian" type, AMM, III, Baku, S.81-97). (in Rus).

Ismagilov 1988 - Ismagilov, RB 1988, Pogrebenie Bol'shogo Gumarovskogo kurgana v YUzhnom Priural'e i problema proiskhozhdeniya skifskoj kul'tury, ASGEH, Vyp.29, S.29-47. (Ismagilov, RB 1988, Komarovskogo a Large Burial mound in the southern Urals and the problem of the origin of the Scythian culture, ASGEH, Vyp.29, S.29-47). (in Rus).

Kashkaj 1973 - Kashkaj, MA, Selimhanov, IR 1973, Iz istorii drevnej metallurgii Kavkaza, EHIm, Baku, 223 s. (Kashkaj, MA, Selimhanov, IR 1973, From the history of ancient metallurgy in the Caucasus, EHIm, Baku, 223 s). (in Rus).

Kashkaj 2004 - Kashkaj, SM 2004, O skifskih pohodah cherez Kavkaz na Blizhnij Vostok, l.Eliyevin 80 illiyinə həsr olunmuş Elmi konfransın materialları, 12 Mart, 2004, Elm, Bakı, S.41-52. (Kashkaj, SM 2004, About the Scythian campaigns through the Caucasus to the middle East, I. Oliyevin 80 illiyinə həsr olunmuş Elmi konfransın materialları, 12 Mart, 2004, Elm, Bakı, S.41-52). (in Rus).

Kaziev 1949 - Kaziev, SM 1949, Arheologicheskie raskopki v Mingechaure, Azərbaycan Maddi Mədıniyyəti, Bakı, T.I, S.9-49. (Kaziev, SM 1949, Archaeological excavations in Mingechaur, Azərbaycan Maddi Mədıniyyəti, Bakı, T.I, S.9-49). (in Rus).

Kesamanly 1980 - Kesamanly, GP, Gusejnova, MA 1980, Otchet pervogo otryada shamhorskoj arheologicheskoj ehkspe-dicii za 1980 g. AMEA Arxeologiya və Etnografiya Institutunun elmi arxivi: Inv. № h-260, Baku, 14 s. + XV tabl. (Kesamanly, GP, Gusejnova, MA 1980, Report of the first Shamkhor detachment of the archaeological expedition in 1980 AMEA Arxeologiya and Etnografiya Institutunun elmi arxivi: Inv. number h-260, Baku, 14 s. + XV tabl). (in Rus).

Kesamanly 1999 - Kesamanly, GP 1999, Arheologicheskie pamyatniki ehpohi bronzy i rannego zheleza Dashkesanskogo rajona, Ağrıdağ, Baku, 179 c. (Kesamanly, GP 1999, Archaeological monuments of the bronze age and early iron Dashkesan region, Ağrıdağ, Baku, 179 c). (in Rus). 
Kirichenko 2007 - Kirichenko, D 2007, Novye materialy k paleoantropologii Azerbajdzhana, Tarix və onun problemləri, №1, S.258-260. (Kirichenko, D 2007, New materials for the paleoanthropology of Azerbaijan, Tarix və onun problemləri, №1, S.258-260). (in Rus).

Kozenkova 1965 - Kozenkova, VI 1965, Issledovaniya Serzhen'-YUrtovskogo poseleniya v 1963 g., Kratkie soobshcheniya Instituta arheologii, Vyp.103, S.67-74. (Kozenkova, VI 1965 researches of the Sergen-Yurt settlement in 1963, Brief reports of the Institute of archaeology, Vyp.103, S.6774). (in Rus).

Kozenkova 1964 - Kozenkova, VI, Krupnov, EI 1964, Issledovaniya Serzhen'-YUrtovskogo poseleniya. Po raskopkam 1964 g., Kratkie soobshcheniya Instituta arheologii, Vyp.106, S.81-87. (Kozenkova, VI, Krupnov, El 1964, Studies of the Serzhen-Yurt settlement. On the excavations of 1964, Short messages of Institute of archeology, Vyp.106, S.81-87). (in Rus).

Kudryavcev 1982 - Kudryavcev, AA 1982, O novoj hronologii drevnego Derbenta, Sovetskaya arheologiya, №4, S.165-186. (Kudryavcev, AA 1982, on the new chronology of ancient Derbent, Soviet archaeology, №4, S.165-186). (in Rus).

Mahortyh 2014 - Mahortyh, S 2014, Ob odnoj gruppe ranneskifskih pamyatnikov Dneprovskogo lesostepnogo Pravoberezh'ya, Revista Arheologica, Vol.X, N1-2, C.69-78. (Mahortyh, S 2014, one of the group of the early Scythian monuments of the Dnieper left Bank forest-steppe, Revista Arheologica, Vol.X, N1-2, C.69-78). (in Rus).

Melyukova 1964 - Melyukova, Al 1964, Vooruzhenie skifov, Nauka, Mockow, 1964, 90 s. (Melyukova, Al 1964, Weapons of the Scythians, Nauka, Mockow, 1964, 90 p). (in Rus).

Muhtarov, Bədəlova, əmrah-qızı 2013 - Muhtarov, N, Bədəlova, I, əmrah-qızı, C 2013, Şəki Arxeologiya və Folklor qrupunun, Şəki-Qax-Oğuz arxeoloji ekspedisiyasının 2013-cü ildə gördüyü işlərin geniş Hesabatı, AMEA Arxeologiya və Etnoqrafiya İnstitutunun arxivi: İnv. №777, Şəki-Bakı, 64 s. + 67 tabl. (Muhtarov, N, Bədəlova, I, Omrah-qızı, C 2013, Şəki Arxeologiya və Folklor qrupunun, Şəki-Qax-Oğuz arxeoloji ekspedisiyasının 2013-cü ildə gördüyü işlərin geniş Hesabatı, AMEA Arxeologiya və Etnoqrafiya İnstitutunun arxivi: İnv. №777, Şəki-Bakı, 64 s. + 67 tabl.). (in Azerb).

Munchaev, Smirnov 1958 - Munchaev, RM, Smirnov, KF 1958, Arheologicheskie pamyatniki bliz sel. Karabudahkent, Materialy $i$ issledovaniya po arheologii SSSR, № 68, 196 s. (Munchaev, RM, Smirnov, KF 1958, Archaeological monuments near the villages. Karabudakhkent, Materials and researches on archeology of the USSR, № 68, 196 s). (in Rus).

Nərimanov, Babayev 1987 - Nərimanov, İH, Babayev, İA 1987, Keçilidə arxeoloji tapıntılar, Azərbaycan Maddi Mədıniyyəti, Bakı, X, S.57-68. (Nərimanov, İH, Babayev, İA 1987, Keçilidə arxeoloji tapıntılar, Azərbaycan Maddi Mədıniyyəti, Bakı, X, S.57-68). (in Azerb).

Ol'hovskij 1997 - Ol'hovskij, VS 1997, Skifskaya triada, Pamyatniki predskifskogo i skifskogo vremeni na yuge Vostochnoj Evropy. Materialy $i$ issledovaniya po arheologii Rossii, №1, S.85-96. (Ol'hovskij, VS 1997, Scythian triad, Pre-Scythian and Scythian time Monuments in the South of Eastern Europe. Materials and research on archeology of Russia, №1, S.85-96). (in Rus).

Polin 1987 - Polin, SV 1987, Hronologiya rann'oskifs'kih pam'yatok, Arheologiya, №59, S.17-36. (Polin, SV 1987, Chronology raniecki pam'yatok, Archaeology, №59, S.17-36). (in Rus).

Plyni 1942 - Plyni 1942, Natural History, Volume II./ trans. by Rackham H., Harvard University Press, Cambridge, 663 p. (in Eng).

Ryabkova 2003 - Ryabkova, TV 2014, Ranneskifskie pamyatniki Nizhnego Podon'ya i Prikuban'ya: Avtoref. dis. ... kand. ist. Nauk, Saint-Petersburg, 24 s. (Ryabkova, TV 2014, The early-Scythian monuments of the Lower don and the Kuban 'area: abstract. dis. ... kand. east. sciences', SaintPetersburg, $24 \mathrm{~s})$. (in Rus).

Ryabkova 2014 - Ryabkova, TV 2014, Kurgan 524 u s. ZHabotin v sisteme pamyatnikov perioda skifskoj arhaiki, RossiĭskiI arheologicheskĭ ezhegodnik, Vyp.4, S.372-432. (Ryabkova, TV 2014, Kurgan $524 \mathrm{u} \mathrm{s}$. Zhabotin in the system of monuments of the Scythian archaic period, Russian archaeological Yearbook, Vyp.4, S.372-432). (in Rus).

Samashev 2011 - Samashev, Z 2011, Berel', Tajmas, Almaty, 236 s. (Samashev, Z 2011, Berel', Tajmas, Almaty, $236 \mathrm{~s}$ ). (in Rus).

Samashev, Ermolaeva, Kushch 2008 - Samashev, Z, Ermolaeva, A, Kushch, G 2008, Drevnie sokrovishcha kazahskogo Altaya, Öner, Almaty, 200 c. (Samashev, Z, Ermolaeva, A, Kushch, G 2008, Ancient treasures of the Kazakh Altai, Öner, Almaty, 200 c). (in Rus).

Skoryj 2003 - Skoryj, SA 2003, Skify v Dneprovskoj Pravoberezhnoj lesostepi, b.i, Kiev, 161 s. (Skoryj, SA 2003, Skythians in the Dnieper right-Bank forest-steppe, Kiev, $161 \mathrm{~s})$. (in Rus).

Stantchev Dimitar 2000 - Stantchev, D 2000, Warrior Burial in the Lower Course of the Yantra, Tombes tumulaires de l'Age du Fer dans le Sud-Est de l'Europe, N1, P.35-44. (in Eng).

Strabon 1964 - Strabon 1964, Geografiya: v 17 knigah, Per. Stratanovskogo G.A., Nauka, Leningrad, 944 s. (Strabon 1964, Geography: in 17 books, Transl. Stratanovskogo G.A., Nauka, Leningrad, 944 s). (in Rus). 
Tairov 2007 - Tairov, AD 2007, Kochevniki Uralo-Kazahstanskih stepeǐ v VII -VI vv. do n.eh., Izd-vo YUUrGU, Chelyabinsk, 274 s. (Tairov, AD 2007, Nomads of Ural-Kazakhstan steppes in VII-VI centuries BC, Izd-vo YUUrGU, Chelyabinsk, 274 s). (in Rus).

Vishnevskaya 1973 - Vishnevskaya, OA 1973, Kul'tura sakskih plemen nizov'ev Syrdar'i v VII-V vv. do n.eh.: po materi-alam Ujgaraka, Nauka, Moscow, 160 s. (Vishnevskaya, OA 1973, Culture of Saka tribes of the lower reaches of the Syr Darya in the VII-V centuries BC, Nauka, Moscow, 160 p). (in Rus).

YAblonskij 1996 - Yablonskij, LT 1996, Saki YUzhnogo Priaral'ya (Arheologiya $i$ antropologiya mogil'nikov), IA RAN, Moscow, 186 s. (Yablonskij, LT 1996, Saki of the southern Aral sea region (Archeology and anthropology of burial grounds), IA RAN, Moscow, $186 \mathrm{~s}$ ). (in Rus).

YAblonskij 2000 - Yablonskij, LT 2000, Glavnye migracionnye processy na territorii YUzhnogo Priaral'ya v rannem zheleznom veke, Nizhnevolzhskij arheologicheskij vestnik, Vyp.3, S.64-83. (Yablonskij, LT 2000, the Main migration processes on the territory of the southern Aral sea region in the early iron age, Nizhnevolzhsky archaeological Bulletin, Issue 3, S.64-83). (in Rus).

Zenobij 1948 - Zenobij 1948, Sokrashchenie iz [sbornikov] poslovic [Lukilla] Tarrejskogo i Didima, sostavlen-noe v alfavitnom poryadke, Vestnik drevnej istorii, №4, S. 289-291. (Zenobij 1948, The reduction of [collections of] Proverbs [Lucilla] Carrascoso and Didyma, drawn-ing in alphabetical order, Bulleten of the ancient history, №4, S.289-291). (in Rus). 